\title{
Scheepswinsten tijdens de negenjarige oorlog [1689-1697]
}

De geschiedenis van de Vlaamse koopvaardij is een onbetreden terrein. Het werk van Van Bruyssel is verouderd en zijn aandacht gaat in de eerste plaats naar de handel; de scheepvaart wordt slechts vermeld in funktie van deze handel ${ }^{1}$. Het ekonomisch belang van deze tak van de nijverheid ontgaat ons dus volledig.

Toch zijn er aanwijzingen dat deze industrie niet zó van alle belang ontbloot was als prof. Van der Wee in 1958 op het Derde Internationaal Congres voor Maritieme Wetenschappen liet uitschijnen ${ }^{2}$. Het is bv. onmogelijk aan te nemen dat de Oostendse Kompagnie, opgericht in $1722^{3}$, niet zou geschraagd zijn door een uitgebreide maritieme kennis, die scheepsbouw, scheepstypes, bevrachting, rederij, onderlegde zeevaarders, rekrutering van bemanning e.d. omvat. We menen zelfs dat het probleem kan omgekeerd worden en dat de pogingen tot oprichting van een dergelijke kompagnie resulteerden uit een drukking van onderuit $\mathrm{nl}$. van de reders-kooplieden, die op een bepaald moment over een overtollige scheepsruimte moeten beschikt hebben, waarvan zij op de traditionele scheepsroutes geen gebruik meer

1. E. Van Bruyssel, Histoire du commerce et de la marine en Belgique, Bruxelles, 1861-1864, 3 dln.

2. Le navire et l'économie maritime du Nord de l'Europe du Moyen-Age au XVIII ${ }^{\mathrm{e}}$ siècle. Travaux du troisième colloque international d'bistoire maritime tenu les 30 et 31 mai 1958, Paris, 1960, blz. 78. Diskussie na de bijdrage van prof. E. Coornaert, Anvers a-t-elle eu une flotte marchande au XVI ${ }^{\mathrm{e}}$ siècle?

3. Zie hierover N. Laude, La Compagnie d'Ostende et son activité coloniale au Bengale (1725-1730), Bruxelles, 1944 (Kon. Belg. Kol. Instituut, afd. Staat en Zedek. Wetensch., verh., XII, afl. 1) en de aldaar geciteerde bibliografie. 
konden maken gezien het verlies van hun konkurrentiële positie.

De oprichting van een Kompagnie voor handel op OostIndië en China dateert echter reeds uit een vroegere periode. Pogingen hiertoe hadden resultaat op 2 juni 1698 onder impuls van Bergeyck ${ }^{4}$. Het bleef op dat ogenblik een konsekwentieloze hersenschim, maar de datum verschaft ons een terminus ad quem. Wanneer onze bovenstaande bewering juist is, moet zich in de periode vóór 1698 een expansie van de Vlaamse koopvaardij hebben gemanifesteerd met een daaropvolgend dieptepunt.

$\mathrm{Nu}$ is expansie het best te meten aan de hand van statistieken doch deze zijn slechts sommair voorhanden en moeilijk te gebruiken ${ }^{5}$.

Expansie betekent echter ook rendabiliteit en in scheepstermen uitgedrukt wijst dit op bevrachting en hoge vrachtprijzen.

4. R. De Schryver, Jan van Brouchoven, graaf van Bergeyck, 1644-1725 (Brussel, 1965. Kon. V1. Acad. Kl. Letteren, verh. 57), blz. 155-165. Reeds voor de Negenjarige Oorlog waren pogingen ondernomen en rekesten ingediend om deelname aan de koloniale handel door de Zuidelijke Nederlanden [Ibidem, blz. 139-142; A. Levae, Recherches bistoriques sur le commerce des Belges aux Indes pendant le $X V I I^{\mathrm{e}}$ et $X V I I I^{\mathrm{e}}$ siècles, in Trésor National, 1 , (1842), blz. 186-188; G. Clark, From the Nine Years war to the war of the Spanish Succession, in The New Cambridge Modern History. VI. The rise of Great Britain and Russia (Cambridge, 1970), blz. 390-391].

5. Er is bv. een lijst van 45 vlaamse schepen, die in Franse havens worden weerhouden als gevolg van de oorlogsverklaring van Spanje aan Frankrijk in mei 1689 [H. Lonchay-J. Cuvelier, Correspondance de la Cour d'Espagne sur les affaires des Pays-Bas au XVII ${ }^{\mathrm{e}}$ siècle, dl. 5, blz. 508-509 (Bruxelles, 1923-1937, 5 dln + supplement)]. Deze lijst geeft echter slechts een deel van de Vlaamse vloot weer. Er worden bv. slechts drie Nieuwpoortse schepen vernoemd, terwijl een andere lijst, opgesteld tussen $1688-1690$, minstens 42 Nieuwpoortse met een tonnemaat van 50 vat en meer vermeld (Gent, Rijksarchief, fds Raad van Vlaanderen, nr. 22514c). Het statistisch materiaal uitgegeven door J. De Smet, Tables du commerce et de la navigation du port de Bruges, 1675-1698, in Handel. Kon. Comm. Gescbiedenis, 94 (1930), blz. 104-244, geeft geen inlichtingen over de thuishaven van de schepen. Verder kan Bergeycks verklaring in 1692 dat de Vlaamse koopvaardijvloot slechts een twaalftal schepen telde, niet ernstig genomen worden ( $R$. De Schryver, Jan van Broecboven..., blz. 85 ). 
Het is echter voor iedereen, die iets afweet van scheepvaart in de $17 \mathrm{e}$ eeuw, duidelijk dat de Vlaamse koopvaardij - evenals de Engelse ten andere - een uitzonderlijk hevige konkurrentie vanwege de Hollanders onderging ${ }^{6}$. Dit zal in Engeland anleiding geven tot een reeks wetten o.m. de befaamde "Act of Navigation" van oktober 1651, die aan de Engelse schepen een expliciete bescherming verleent bij de import. De Engelse scheepvaart zal hierdoor een duidelijke stimulans ondergaan?

In de Zuidelijke Nederlanden kwam een dergelijke protektionistische maatregel niet voor, zodat het aan de kreativiteit van de reder overgelaten werd om deze moordende konkurrentie het hoofd te bieden ${ }^{8}$. Het ligt voor de hand dat de winst door de Vlaamse schepen gerealiseerd - indien er was - uitzonderlijk laag moet zijn geweest. We willen hier enkel het voorbeeld aanhalen van de verliezen geleden door de Oostendse reder, David

6. De Hollanders hadden het voordeel dat zij de handel tussen de Baltische Staten en Zuid-Europa beheersten en aldus een vracht op heen- en terugreis in de wacht sleepten nl. hout en graan uit het Noorden tegen zout en wijn uit het Zuiden (R. Davis, The rise of the Englisch shipping industry in the seventeenth and eighteenth centuries, London, 1962, blz. 187; V. Barbour, Dutch and English merchant shipping in the seventeenth century, in Essays in Economic History, uitg. door E.M. Carus-Wilson, Londen, 1955, blz. 231, 237 en vlg.).

7. Nopens deze "Act of Navigation », cfr. L.A. Harper, The English Navigations Laws. A seventeenth century experiment in social engineering (New York, 1964, reprint). De gevolgen hiervan voor de Engelse scheepvaart worden behandeld in R. Davis, The Rise..., blz. 12-13 en meer gedetailleerd bij R. Davis, English foreign trade, 1610-1700, in W.E. Minchinton, The growth of English overseas trade, Londen, 1969, blz. 78-99.

8. Er bestaat een betoog opgesteld door een onbekende, doch te dateren vóór 1658 (Duinkerke was immers nog Spaans bezit), waarin aangedrongen wordt om Duinkerke en Oostende als doorvoerhavens voor de goederen uit de Baltische staten met bestemming Centraal Europa te laten fungeren (Gent, Rijksarchief, fds Raad van Vlaanderen, $1^{\circ}$ reeks, 1078). In het zoeken naar nieuwe gebieden en routes zou ook de Brugse Groenlandvaart tussen 1664 en 1673 kunnen ingeschakeld worden (A. Van Zuylen Van Nyevelt, La pêche à la baleine et les brugeois au XVII siècle, in Annales de la Société d'Emulation de Bruges, LXVII (1924), blz. 47-53). 
Regaus, met zijn schepen de "St Philippe" en de „St Jan" in $1673^{\circ}$.

Met het uitbreken van de Negenjarige Oorlog (1688 . 1697), waarbij Spanje en de Zuidelijke Nederlanden zich in 1689 aan de zijde van Engeland en Holland scharen in de strijd tegen Frankrijk ${ }^{10}$, komt echter het ogenblik dat zowel Holland als Engeland uit bepaalde scheepsroutes verdwijnen nl. uit de handel met Frankrijk ${ }^{11}$, zodat deze konkurrentie voor de Vlaamse schepen opgeheven wordt. Deze medaille heeft echter ook een keerzijde : het gevaar voor kapers, hoge verzekeringskosten, hoge loonlasten en soms zeer langdurige reizen. Nochtans zullen deze ", fransvaarders" steeds een doorn blijven in het oog van de Republiek, die gedurende gans de duur van de oorlog

9. «Over $1 / 8$ part in $309 \mathrm{fl}$. soo veel het schip St Philippe te quorte van 3 eersten voyagen » (Gent, Rijksarchief, fds Raad van Vlaanderen, $1^{\mathrm{e}}$ reeks, 1080). Daarentegen werd wel winst gemaakt tussen 1666-1670.

10. H. Lonchay-J. Cuvelier, Correspondance..., dI. 5, n ${ }^{\circ} 1320,1322$ (mei 1689). Voor Holland en Engeland speelden ook ekonomische elementen mee in de strijd tegen Frankrijk o.m. de afsluiting van Antwerpen; deze haven zou bij eventuele openstelling door de Fransen in korte tijd Londen en Amsterdam als doorvoerhaven van Centraal Europa hebben overtroffen [R. Mousnier, Les XVI ${ }^{\circ}$ et XVII siècles. Le progrès de la civilisation européenne et le déclin de l'Orient (1492-1715), blz. 279 (Histoire générale des Civilisations. IV, Parijs, 1957-1959, $7 \mathrm{dln}]$.

11. Engeland en Holland sloten in oogst 1689 een overeenkomst waarbij aan weerszijden besloten werd iedere handel met Frankrijk te verbieden. G.N. Clark, The Dutch Alliance and the war against French trade, 1688-1697, Manchester, 1923, blz. 64. Dit wordt ten andere bewezen door de havenbeweging van St.-Malo uit die jaren. Er worden vanaf 1689 geen Rotterdamse en Amsterdamse schepen meer genoteerd ( $\mathrm{J}$. Delumeau, Le mouvement du port de Saint-Malo, 1681-1720. Bilan statistique, Paris, 1966, blz. 194-199). Hollanders zowel als Engelsen hebben dit verbod omzeild (G.N. Clark, The Dutch Alliance..., blz. 70-71). Een zeer duidelijk voorbeeld van dergelijke smokkel kan men vinden in een schrijven van Jan Colck uit Rotterdam aan C.F. de Pouillon te Gent op 31 december 1694 : «Voorleeden weeck is hier een scheeptie direct van Nantes in de Maas gekoomen met Anjoue wijn in poortze pijpen, dat met een aerdigheijt gaeuw gelost is en van d'eene packhuijs int andre gebrogt». In 1695 is er regelmatig sprake van aanvoer van wijn en brandewijn langs Duinkerke door Willem van Nes uit Amsterdam in kompagnie met de voornoemde de Pouillon uit Gent (Gent, Rijksarchief, Raad van Vlaanderen, nr. 13.526). 
bij Maximiliaan-Emmanuel zal aandringen op het beëindigen van de vaart op Frankrijk. Zij zag immers deze handel als een steun aan de vijand. Of was ze bevreesd dat de Zuidelijke Nederlanden van deze gelegenheid zouden gebruik maken om hun plaats als schakel tussen de NoordEuropese en Zuid-Europese handelsgebieden in te nemen ? Dit denkbeeld is niet zo vreemd als op het eerste gezicht lijkt wanneer we de omschakeling van de Vlaamse koopvaardij zien onmiddellijk na het stopzetten van de oorlog ${ }^{12}$. In ieder geval lukt de Republiek er in op sommige momenten de verbinding Vlaanderen - Frankrijk te verbreken zoals in juni $1694^{\mathrm{B}}$.

En in het kader van het voorgaande mag niet uit het oog verloren worden dat de Republiek reeds vóór 1688 duidelijk de impakt van Engeland en Frankrijk op haar dominante ekonomische positie voelde. Tegen het einde van de 17 e eeuw zou zij over haar hoogtepunt heen zijn ${ }^{14}$, zodat Bergeycks belangstelling voor de haven van Oostende - bij ontstentenis van Antwerpen - in het verlengstuk van dit algemeen Europees patroon komt te liggen ${ }^{15}$. Het is de vraag of de Vlaamse reders van deze gele-

12. Het fluitschip de «St. Pieter» vertrok op 15 april 1699 te Oostende naar Le Croisic (arr. St.-Nazaire; dep. Loire-Inférieure), vandaar naar Riga en terug met een lading hout naar Oostende (Brugge, Rijksarchief, fds Nieuwpoort, 5876; voortaan afgekort tot $\mathrm{RAB}, \mathrm{Npt}$ ).

13. R. De Schryver, Jan van Broechoven, blz. 85-86.

14. P. Jeannin, L'Europe du Nord-Ouest et du Nord aux XVII et XVIII ${ }^{\mathrm{e}}$ siècles, Paris, 1969, blz. 304-338; P. Leon, Economies et sociétés préindustrielles, Paris, 1970, II, blz. 118, 121-125 ; C. Wilson, England's apprenticeship, 1603-1763, Londen, 1965, blz. 160-184; R. Davis, English foreign trade, 1700-1774, in W.E. Minchinton, The growth of English Overseas trade, blz. 99-118; C.H. Wilson, The economic decline of the Netherlands, in Essays in economic history, door E.M. Carus-Wilson, Londen, 1955, blz. 254-269; M. Morineau, La balance du commerce franco-néerlandais et le resserrement économique des Provinces-Unies au XVIII ${ }^{\mathrm{e}}$ siècle, in Economisch Historisch Jaarboek, (1961), blz. 170-233 ; J.M. Price, Economic activity. I : The map of commerce, 1683-1721, in The New Cambridge Modern History. VI The rise of Great Britain and Russia, 1688-1725, Cambridge, 1970, blz. 838-850.

15. R. De Schryver, Jan van Broechoven..., blz. 81. 
genheid hebben gebruik gemaakt en indien wel, of de rendabiliteit voldoende was om aanleiding te geven tot een uitbreiding van de vloot.

Gegevens hiervoor zijn er nu bepaald niet in overvloed. In het archief van de stad Nieuwpoort steken nochtans de financiële dokumenten betreffende het uitreden van een hoeker ${ }^{16}$ de "St Fransois" in 1695 voor de vaart op Bordeaux ${ }^{17}$. Het dossier is enkel volledig voor de tweede reis, doch kan aangevuld worden met details bewaard in de briefwisseling die de boekhouder van het schip onderhield met zijn overzeese korrespondenten, zodat een betrekkelijk volledig beeld van de eerste twee reizen (1695 1697) van deze hoeker kan gerekonstrueerd worden, samen met een overzicht van de uitgaven, de inkomsten en natuurlijk de winst. Dit materiaal zou een antwoord moeten kunnen geven op de vraag naar de rendabiliteit van Vlaamse schepen tijdens deze bewogen periode.

1.

De voornoemde hoeker had Duinkerke als thuishaven en het is aan te nemen dat Jacques van der Haeghe, koopman te Duinkerke ${ }^{18}$, aan Carel de Vleeschouwer,

16. De hoeker was oorspronkelijk het type van een vissersvaartuig, doch ontwikkelde zich in de loop van de $17^{\circ}$ eeuw tot een koopvaardijschip. Grote hoekers hadden drie masten. Kenmerkend voor de hoeker is ook de ronde bodem, die voor en achter sterk opliep. Hij behoorde tot de meest zeewaardige schepen en werd vooral gebruikt voor de vaart op de Noordzee, Spanje en de Middellandse Zee. Er liepen te Rotterdam betrekkelijk veel hoekers van stapel (S.C. Van Kampen, De Rotterdamse particuliere scheepsbouw in de tijd van de Republiek, Assen, 1953, blz. 56; J. Van Beylen, Scbepen van de Nederlanden van de late Middeleeuwen tot bet einde van de $17^{\mathrm{e}}$ eeuw, Amsterdam, 1970, blz. 125; Cornelis Van Yk, De Nederlandsche Scheepsbouw-Konst open gestelt, Amsterdam, 1697, blz. 301-308 met bestek en profieltekening van een hoeker; een driemasthoeker wordt afgebeeld bij G. Groenewegen, Verzameling van vier en tachtig stuks Hollandscbe Scbepen, Rotterdam, 1789, C 8).

17. RAB, Npt, 4866 bis.

18. Over de belangrijkheid van de Van der Haghe's te Duinkerke, cfr. A. Bonvarlet, Le livre du bailli de l'église de Dunkerque, in Annales du Comité Flamand de France, XIV (1877-1883), blz. 76 ; A. Bouly de Lesdain, Anciennes familles Dunkerquoises. Généalogie 
koopman te Nieuwpoort ${ }^{19}$ een hint gaf dat deze hoeker met drie masten door een Zeeuws oorlogsschip te Vere was opgebracht ${ }^{20}$. In ieder geval is het Vleeschouwer, die aan zijn korrespondent Gillis Roelens te Middelburg inlichtingen vraagt ${ }^{21}$. Deze laatste verzekert hem op 17 september 1695 dat er inderdaad te Vere een hoeker met drie masten en veertien stukken kanon werd binnengebracht. Hij zal hem bericht zenden wanneer de verkoop ervan doorgaat, maar doet tevens opmerken dat er soms slechts 8 dagen verlopen tussen het aanplakken en de verkoop ", soo datter geen tijt sau wesen om UE daer over te advyseren". Hij zal proberen een inventaris te zenden ${ }^{22}$. Intussen is Vleeschouwer reeds met Van der Haeghe overeengekomen dat hij bij eventuele ankoop 1/6 part in het schip zal nemen en hij stuurt schipper Joannes Looten naar Vere om de hoeker te bezichtigen ${ }^{23}$.

de Brier, 1587-1794, in Bulletin de l'Union Faulconnier, XXXIII (1936), blz. 84. De Duinkerkse poorterij in het algemeen wordt behandeld door R. Weexsteen, La bourgeoisie Dunkerquoise de 1662 à 1789, in Bulletin du Comité Flamand de France, XVI (1959), blz. 287-291.

19. Er is weinig gekend over Carel de Vleeschouwer. W. Debrock spreekt over "un armateur en course, très connu de Nieuport" (W. Debrock, L'Amirauté d'Ostende, Oostende, s.d., blz. 34). Hij werd vermoedelijk in 1653 geboren te Oostende als zoon van de kuiper Joos de Vleeschouwer (RAB, Npt, 5869). Deze Joos behoorde in 1657 tot de belangrijke reders van Oostende (W. Debrock, Een mutualiteitskas van de Oostendse reders ter kaapvaart, 1657-1716, in Handelingen van het Genootschap voor Geschiedenis te Brugge, XCVII (1960), blz. 101-102). Carel de Vleeschouwer voerde reeds in 1675 handel met Nantes (RAB, Npt, 5884), en werd schepen van de stad Oostende. Op 12 december 1673 huwde hij te Nieuwpoort met Catharina Soudelynck (RAB, Npt, 329, f $\mathrm{f}^{\circ} 124$ ). Eerst rond 1688 verschijnt hij te Nieuwpoort, waar hij als poorter aanvaard wordt in 1692 (RAB, Npt, 170, $f^{\circ} 109$ ). Hij sterft te Nieuwpoort in 1718 en wordt er begraven op 15 december 1718 (RAB, fonds Parochieregisters, Nieuwpoort, 28).

20. De Zeeuwse kaapvaart wordt behandeld door G.N. Clark, The Dutch Alliance..., blz. 44-55, 148.

21. Kort te voren had Vleeschouwer aan Marc Fletcher te Middelburg navraag gedaan voor aankoop van een snauw of een frans fregat (16 à 18 stukken). Brief van Fletcher aan Vleeschouwer, 17 september 1695 (RAB, Npt, 5867).

22. Ibidem, 5889.

23. Van der Haeghe an Vleeschouwer, Duinkerke 21 sept. 1695 
Op 23 september zendt Looten een verslag over dit schip : „...ick het schip ofte den hoecker ghesien hebbe. Ghesteltenisse van dit schip is wel en oock van de rondthouten en van het loopende en de staende wandt is wel als het niet vermindert en woordt. Aengaende van het gheschodt, sij hebber tot daete dese noch bij het schip ghelaeten twee zes ponders en de 6 vijer ponders en vijer drij ponders en twee twee ponders. Als ick hier eerst quam, soo waerender noch sesthien, maer hebber eergister sijen twee verkoopen aen Pieter Klouw. Het waeren twee 4 ponders ${ }^{24}$. Aengaende van de zeijlen, daer en manqueert geen seijlen tot het schip als een lijee seil ${ }^{25} \ldots$ Aengaende de koorden wel, de hanckers zijn gheele wel, maer en is geen boodt, noch geen handtgheweren, noch geen fuijctaeillije". Bij eventuele aankoop zouden meer manschappen moeten overkomen, gezien ", het volck is hier seere diere" ${ }^{26}$.

Op 1 oktober 1695 gaat de verkoop tot Vere door. De hoeker wordt gekocht door Roelens in naam van Vleeschouwer voor een bedrag van 1.351 pond groot ${ }^{27}$. Op 25 oktober zal Roelens Vleeschouwer echter debiteren voor 1.846 pond groot (of $11.950 \mathrm{fl}$. courant) ${ }^{28}$. Het

(Ibidem, 5888). Joannes Looten was reeds kapitein geweest in dienst van Vleeschouwer. In 1693 was hij schipper op een smakschip dat regelmatig naar Rotterdam en Middelburg zeilde (Ibidem, 5864, $f^{\circ} 43$ ).

24. Hiermede bedoelde men kanonnen van kaliber $6,4,3$ en 2 ofwel kanonnen die in staat waren kogels van $6,4,3$ en 2 pond af te schieten. Over de bewapening van de schepen in die tijd, cfr C. Van Yk, De Nederlandsche Scheepsbouw..., blz. 262 en vlg.; J. Van Beylen, Schepen van de Nederlanden..., blz. 73-78; F.L. Diekerhoff, De oorlogsvloot in de zeventiende eeuw, Bussum, 1967, blz. $43-51$.

25. Vermoedelijk het grote lijzeil (C. Van Yk, o.c., blz. 257).

26. RAB, Npt., 5883 .

27. Roelens aan Vleeschouwer, Middelburg 1 oktober 1695 (Ibidem, 5889).

28. Rekening-kourant van Roelens met Vleeschouwer, april-november 1695 (Ibidem, 5889). De omzetting van pond vlaams in gulden courant gebeurt als volgt : 1 pond vlaams $=6$ gulden wisselgeld; voor omzetting van wisselgeld in courantgeld moet vermenigvuldigd worden met $13 / 12$. 
verschil houdt vermoedelijk verband met de aankoop van allerlei materiaal, dat uit het schip verdwenen was en waarover Looten in zijn verslag van 23 september had geschreven. Later zal Looten nog meedelen dat er een lijzeil, een voormarszeil en een grootstengestagzeil werden gekocht ${ }^{29}$. De betaling van deze aankoop wordt gefinancieerd door wisselbrieven o.m. op Pieter Mogghe tot Zierikzee en op de firma's Valck en Leuven en Pieter Block te Rotterdam, waar Vleeschouwer een deel fondsen voortspruitend uit terugbetalingen van gelden, voorgeschoten aan het Hollands garnizoen te Nieuwpoort, akkumuleerde ${ }^{30}$.

Van der Haeghe wenst Vleeschouwer op 6 oktober ${ }^{31}$ geluk met deze ankoop en deelt mee dat hij bij de rechter van de Admiraliteit te Duinkerke een frans paspoort voor de hoeker heeft aangevraagd. Verder moet het mogelijk zijn dit schip „a droiture" van Zeeland naar Duinkerke te laten zeilen, gezien twee Oostendse reders, Clerck en Van Aecken ${ }^{32}$, hierin gelukt zijn. Verder zou de hoeker moeten geladen worden met 200 zakken witte zeeuwse boontjes en kolen van Newcastle of Sunderland ${ }^{33}$ want op "teene en tander isser groot gelt te winnen. Daarom ist best dat wij dit int passant meede neemen". $\mathrm{Er}$ is nog tijd genoeg om naar Bordeaux te zeilen, gezien de slechte weersomstandigheden de druivenoogst merkelijk vertraagd hebben ${ }^{34}$.

29. Looten aan Vleeschouwer, 4 november 1695 (Ibidem, 5883). Uitzicht, vorm en lokalisatie van deze zeilen, zie T. Tryckare, Spiegel der zeevaari. Nautische encyclopedie, Amsterdam, 1963, blz. 80, 101.

30. Rekening-kourant van Roelens met Vleeschouwer, april-november 1695 (Ibidem, 5889); Van der Haeghe aan Vleeschouwer, Duinkerke 6 oktober 1695 (Ibidem, 5888).

31. Van der Haeghe aan Vleeschouwer, Duinkerke 6 okt. 1695 (Ibidem).

32. Antoon van Aecken wordt vernoemd als Oostends reder van een galjoot de "St Fransois » (H. Lonchay-J. Cuvelier, Correspondance..., V, blz. 508).

33. Over de engelse kolenproduktie en uitvoer ervan naar Holland en Vlaanderen, zie J.U. Nef, The rise of the British coal industry, Londen, 1966, 2 dln, reprint, I, blz. 87, 93-94; dl. 2, blz. 229-231.

34. De druivenoogst was in 1695 inderdaad laat, zie de tabellen 
Vleeschouwer werkte deze plannen van Van der Haeghe verder uit. Kolen en boontjes werden te Middelburg besteld. Een kolenvloot wordt binnen enkele dagen te Zierikzee verwacht; Roelens geeft opdracht voor aankoop van een drietal hoekers ${ }^{35}$. Tegenslag is wel dat de boontjes niet mogen uitgevoerd worden, waarop Van der Haeghe suggereert 100 tonnen kabeljauw te kopen ${ }^{36}$. Momenteel is dit het enige Hollandse produkt waarop te Duinkerke enig geld kan verdiend worden, want Van der Haeghe is de mening toegedaan: "Wij moeten sien dat wij uijt de vis en de coolen d'helft van ons schip inwinnen " ${ }^{37}$. Doch te Zierikzee is praktisch geen gezouten vis te krijgen. Wat voorhanden is, is slecht en zeer duur $\left(18^{1 / 2} / 2\right.$ à $19 \mathrm{fl}$. de ton op zee verpakt). De Brabanders schijnen alles opgekocht te hebben ${ }^{38}$. Daarom worden de 100 ton te Rotterdam besteld ${ }^{39}$. De uitvoering van deze bestelling, waar-

bij E. Le Roy Ladurie, Histoire du climat depuis l'an mil, Paris, 1967, blz. 324. In een brief gedateerd Bordeaux 22 oktober 1695 schrijft de weduwe J. Clock aan Guillaume Looten te Nieuwpoort «...maer daer en presenteere nogh geen goederen door dat wij neevens d'andre coopluijden geen advisen noch hebben conne geeven hoedaenigh de wijnen worden bevonden, alsoo men nogh niet generaelelijck heeft begonne te vendangeeren, twelcke vreese UE magtig sal prejudicieere...» (RAB, Npt, 5461).

35. Roelens aan Vleeschouwer, Middelburg 15 okt. 1695: «Volgens Ul order soo hebbe order geven om drije houckers coolen te coopen, daer van al advys van Zierikzee hebbe, datter alle dag 16 à 17 houckers met coolen staen te arriveren " (Ibidem, 5889).

36. Van der Haeghe aan Vleeschouwer, Duinkerke 13 okt. 1695 (Ibidem, 5888). De kabeljauwvisserij was gevestigd in de steden langs de Maas en te Zierikzee. De steden langs de Maas distribueerden een groot deel van hun vangst langs Rotterdam (H.A.H. Kranenburg, De zeevisscherij in den tijd van de Republiek, Amsterdam, 1946, blz. 47-48). Voor de Negenjarige Oorlog zond Holland een flink deel van zijn haring-en kabeljauwvangst naar Frankrijk (J.M. Price, Economic activity. 1. The map of commerce, 1683-1721, in The New Cambridge Modern History. VI : The rise of Great Britain and Russia, blz. 849).

37. Van der Haeghe aan Vleeschouwer, 15 oktober 1695 (Ibidem, 5888),

38. Looten aan Vleeschouwer, 8 november 1695 (Ibidem, 5883).

39. Van der Haeghe aan Vleeschouwer, 24 oktober 1695 (Ibidem, 5888). In de tweede helft van de $17^{\circ}$ eeuw wordt Middelburg door Rotterdam overklast (W.S. Unger, Geschiedenis van Middelburg in omtrek, Middelburg, 1966, blz. 43). 
van we overigens niets afweten, zal waarschijnlijk een van de redenen zijn waarom het zo lang duurde eer Looten uit Zeeland vertrok. Immers op 22 oktober had Roelens bericht gezonden dat Looten kon uitzeilen : hij heeft 21 "eters" aan boord; "daer en mancquert niets" 40 .

Een andere reden voor het oponthoud was de dood van Lootens vader, Guillaume Looten, waardoor de schipper verplicht was naar Nieuwpoort terug te keren ${ }^{41}$.

Dit tijdverlies veroorzaakte moeilijkheden. De hoekers met hun lading kolen liggen te Zierikzee in afwachting gelost te worden, doch Looten ligt nog steeds te Vere. De reders eisen een vergoeding voor de supplementaire ligdagen ${ }^{42}$. Op 27 oktober kan Looten eindelijk naar Zierikzee varen, waar de 125 hoed Sunderlandse kolen geladen worden $^{43}$. Op 10 november 1695 vertrekt hij naar Duinkerke met zijn lading kolen en gezouten vis ${ }^{44}$.

In navolging van Clerck en Van Aecken was Vleeschouwer in het bezit gekomen van een Spaans paspoort gedateerd 7 oktober 1695 , dat een reis naar Duinkerke en andere Franse havens waarborgde : „...à Jehan Lotten de Nieuport, maistre du navire nommé St François, du port de 168 tonneaux de pouvoir alleer avecq le dit navire chargé de charbons de Zelande es havres de France et $\mathrm{y}$ charger des vins, brandevins et autres marchandises permises et licites et les amener à Ostende ou à Bruges" 45 .

40. Roelens aan Vleeschouwer, 22 oktober 1695 (Ibidem, 5889).

41. Roelens aan Vleeschouwer, 27 oktober 1695 (Ibidem); Guillaume Looten werd op 27 oktober 1695 te Nieuwpoort begraven (RAB, fds parochieregisters Nieuwpoort, 28). Guillaume Looten was zelf schipper geweest en wordt als zodanig vernoemd te Rotterdam, waar hij $271 / 2$ last haver vervoerde naar Gent (RAB, Npt, 5462).

42. Roelens aan Vleeschouwer, Middelburg 22 okt. 1695 en 27 okt. 1695 (Ibidem, 5889) ; Van der Haeghe aan Vleeschouwer, Duinkerke, 29 okt. 1695 (Ibidem, 5888).

43. Roelens aan Vleeschouwer, 29 oktober en 5 november 1695 (Ibidem).

44. Roelens aan Vleeschouwer, 10 november 1695 (Ibidem).

45. Brussel, Alg. Rijksarchief, fds Admiraliteit, 575, ongefolieerd. Het paspoort werd door de solliciteur Pieter Broeck uit Brussel aan Vleeschouwer gestuurd (RAB, Npt, 5867). 
Dit paspoort werd op 17 oktober geregistreerd op de greffie van de Oostendse Admiraliteit, waar Vleeschouwer zich voor een bedrag van $6.000 \mathrm{fl}$. moest borg stellen „, en de dat ter cause van den schepe ghenaemt Ste Francois, daerup mre schipper is Jan Looten van Nieuport, directelick sal gaen van Zeelant naer de havens van Vranckrijck met laedinge van coolen en de van daer weeder te keeren naer deze stadt ofte Brugge met laedinge van wijn, brandewijn en de andere ghepermiteerde goederen sonder de selve te sullen brengen in eenige andere havens van de vijanden van Sijne Majesteijt" ${ }^{46}$. Dit verontrustte Vleeschouwer wel enigszins, gezien hij hierover aan Van der Haeghe schreef, die hem echter verzekerde dat de hoeker te Bordeaux zou geladen worden met bestemming Brugge : "Dat is meede onse intentie" ${ }^{47}$.

Met het vertrek van Looten uit Zierikzee deelt Roelens Vleeschouwer tevens mee dat hij bereid is $1 / 16$ deel $^{48}$ in de hoeker te nemen, zodat de eigendomsverdeling er als volgt uitziet ${ }^{49}$ :
$1 / 3+1 / 24$ Jacques van der Haeghe (Duinkerke)
1/3 Nicolas Taverne (Duinkerke)
1/6 Carel de Vleeschouwer (Nieuwpoort)
1/16 Guillaume Looten (Nieuwpoort)
$1 / 16$ Gillis Roelens (Middelburg)

46. Ibidem. Over deze borgstelling schrijft Broeck aan Vleeschouwer op 29 september 1695 : "Soo heeft S.H.E. een decret gesonden aen den Raedt van Staten en de in d'Audiencie van in alle pasporten te inserreren eene borge van 6 à 7 duijsent gulden te stellen om dat de schepen souden comen in de havens van den Coninck. t'Is een formaliteijt, die en wat moyelyck is, maer mits den prince het soo begeert, soo moeten wij patiencie nemen » (RAB, Npt, 5867).

47. Van der Haeghe aan Vleeschouwer, Duinkerke 20 oktober 1695 (Ibidem, 5888).

48. Roelens aan Vleeschouwer, Middelburg 12 november 1695 (Ibidem, 5888).

49. De eigendomsverdeling van de hoeker komt voor in de rekening van $H$. Sauvage gedateerd 21 januari 1696 met uitzondering van de delen van Roelens en Looten (RAB, Npt, 5893). Looten's deel wordt geciteerd in een brief van Roelens aan Vleeschouwer, 19 november 1695 (Ibidem, 5889). Over scheepsaandelen in het algemeen zie R. Davis, The rise..., blz. 81-109. 
Looten bereikt Duinkerke op 23 november 1695, waar de kolen en de vis onmiddellijk gelost worden ${ }^{50}$. De verkoop ervan verloopt echter niet zo vlot als door Van der Haeghe voorzien. Looten schrijft op 30 november dat de kolen moeten gestapeld worden gezien tot op heden slechts 50 razieren à $10 \mathrm{lb}$. verkocht werden. $\mathrm{Zij}$ worden daarom in een galjoot overgeslagen opdat de hoeker zo spoedig mogelijk vrij zou zijn om ballast in te nemen ${ }^{51}$. Ook de vis vindt te Duinkerke geen afzet en wordt doorgezonden naar Amiens; de afrekening hiervan liet tot einde juni 1696 op zich wachten ${ }^{52}$. Geen wonder dat Roelens op 10 maart 1696 vraagt : „Sal eens geerne vernemen watter van laeding en visch is gecomen en wie de penningen heeft $" 53$.

Terwijl de kolen gelost werden, verzocht Van der Haeghe om een zeebrief voor Looten. Deze zeebrief moest te Oostende of Nieuwpoort geregistreerd zijn, anders bestond er gevaar dat , eenigh renconter hebbende van een engelsman ofte zeeuw bij faute van zeebrieven, sij souden hem opvoeren " 54 .

Vermoedelijk vertrekt Looten naar Bordeaux rond 3 december 1695 in gezelschap van een franse vloot en wordt door Van der Haeghe geadresseerd aan Hyacint Sauvage, koopman te Bordeaux ${ }^{55}$. De reis schijnt vlot verlopen te zijn met uitzondering van een kort oponthoud

50. Van der Haeghe an Vleeschouwer, Duinkerke 24 november 1695 (Ibidem, 5888).

51. Looten aan Vleeschouwer, 30 november 1695 (Ibidem, 5883).

52. Van der Haeghe aan Vleeschouwer, 23 mei 1696 en 30 juni 1696 (Ibidem, 5888).

53. Roelens aan Vleeschouwer, Middelburg 10 maart 1696 (Ibidem, 5889).

54. Van der Haeghe aan Vleeschouwer, Duinkerke 26 november 1695 (Ibidem, 5888). De zeebrief bewijst de thuishaven van het schip (Diderot-D’Alembert, Encyclopédie Méthodique. Commerce, Paris, 1783-1784, 3 dln, III, s.v ${ }^{\circ}$ Lettres de mer. De zeebrief was verplichtend volgens het «Reglement de marine» van 9 juni 1672 (Placcaetboeck van Vlaenderen, III, vol. 2, Gent, 1685, blz. 657).

55. Van der Haeghe aan Vleeschouwer, 1 december 1695 en 11 december 1695 (Ibidem, 5888). 
te $\mathrm{La}$ Hogue rond 15 december ${ }^{56}$. Met de jaarwisseling ligt Looten te Bordeaux, waar onmiddellijk de nodige maatregelen voor de lading van het schip genomen worden ${ }^{57}$.

De vrachtprijs werd gesteld op 110 gulden wisselgeld per vat en drie gulden voor het kaplaken, wat een uitzonderlijk hoge prijs was ${ }^{58}$. Doch de omstandigheden waren abnormaal.

Hoger werd reeds gewezen op de pogingen die Weede van Dijckvelt, ambassadeur van de Republiek te Brussel, ondernam om deze Franse handel stop te zetten, doch steeds hield Bergeyck het been stijf en verklaarde dat de inkomrechten, die uit deze handel voortvloeiden, noodzakelijk waren voor de instandhouding van het leger ${ }^{59}$. Toch moet hij soms voor korte tijd toegeven zoals in juni 1694 , zodat geen paspoorten meer gegeven worden. Was in december 1695 een nieuw verbod op komst? Op 22 december 1695 vraagt Van der Haeghe: „Men seght hier voor vast dat de comercie tusschen Franckeriik en Spagnie wederom sal gebroocken worden. Conde UE. noch een paspoort obtineere voor Joannes Looten om noch eene voyagie na dese te connen doen, dat waere een goede affaire" ${ }^{60}$. Ook Roelens heeft hierover geruchten opgevangen, want hij is overtuigd dat ", op de tijdinghe datter geen pasporden sullen meer geiven worden" de vrachten tot minstens 110 gulden zullen oplopen ${ }^{61}$.

56. Van der Haeghe aan Vleeschouwer, Duinkerke 15 december 1695 (Ibidem, 5888); Looten had te kampen met tegenwind.

57. H. Sauvage aan Vleeschouwer, Bordeaux 3 januari 1696 (Ibidem, 5896); hij zal Looten op 4 januari beginnen te laden. "Hoope dan in koorten geexpedieert zal zijn, waer toe ik mijne zorge niet zal naelaeten om de onkosten van soo een schip te menageeren ».

58. Ibidem.

59. R. De Schryver, Jan van Broechoven..., blz. 85-86 ; H. LonchayJ. Cuvelier, Correspondance..., V, nrs 1536 (1692), 1601 (1694), 1712 (1696).

60. Van der Haeghe aan Vleeschouwer, Duinkerke 22 december 1695 en 24 december 1696 (Ibidem, 5888).

61. Roelens aan Vleeschouwer, Middelburg 21 januari 1696 (Ibidem, 5889). 
Te Bordeaux spelen echter nog andere faktoren een rol. Looten meldt dat hij algauw vaststelde dat de plaatselijke kooplieden niet geneigd waren $110 \mathrm{fl}$. te geven. Er lagen immers een aantal andere schepen (voorzien van 14, 24 en 26 stukken geschut), die hun vracht op $75 \mathrm{fl}$. hadden gesteld, zodat Looten zijn prijs verminderde tot $100 \mathrm{fl} .{ }^{62}$. Ook Sauvage is overtuigd dat de bedongen 100 fl. , een reedelijke vraght is, maert dat dito schip koorten tijdt, soo hoope, hier leggen zall". Er was wel enige konkurrentie van Vlaamse schepen. Sommige Brugse en Oostendse lagen er reeds twee maanden. Een aantal kapiteinen worden vernoemd : Jan Kettey, Michiel van Stavel, Pieter de Corte, Jan Steel, Laurens Reuben, de snauw „ de Fontaine". Er speelde gelukkig één punt in Lootens voordeel $\mathrm{nl}$. de grote bemanning, die bestond uit 28 man en 4 jongens : „, dat is ten deele dat de cooplijeden sulcke goede geneghentheijdt hebben gehadt tot ons en om dat wij stercker gemandt sijn als onse vlaemsche schepen met 24 stuijcken". Wegens de hieruit voortspruitende hoge loonlast moet gezorgd worden voor een korte reis. Looten bereikt - na de verlaging van zijn vrachtprijs - in vijf dagen zijn volle lading, zodat hij 22 januari 1696 vertrekkensgereed ligt ${ }^{63}$. In deze volle lading (168 vat) was begrepen 25 vat wijn en brandewijn aangekocht voor rekening van de reders en 20 vat wijn bestemd voor Vleeschouwer in kompagnie met Jan Priem van Brugge. De rest (123 vat) was bestemd voor kooplieden te Brugge, Oostende en Nieuwpoort ${ }^{64}$.

62. Lootens verslag aan Vleeschouwer is gedateerd 22 januari 1696 (Ibidem, 5883).

63. Sauvage aan Vleeschouwer, Bordeaux 3 januari 1696 (Ibidem, 5896 ) en Lootens verslag van 22 januari (zie voorgaande nota).

64. Een detail van de 168 vat lading steekt in de map van H. Sauvage en is gedateerd 18 mei 1696 te Oostende: "Schipper Joannes Lootens commende van Bordeaux met dese navolgende goederen te lossen te Brugge » (RAB, Npt, 5896); de bevrachters zijn : (Oostende) Mattheus de Moor, Cornelis de Waele, Robert Mutloe, Thomas Baker, Henri de Waele, Michiel Hagens, Pieter Stijps ; (Brugge) Jan Spicket en Nicolaas de Witte, Vleeschouwer en Jan 
Er waren wel enige moeilijkheden met de bemanning, waardoor Looten verplicht was een ", barbier" in dienst te nemen en aan de manschappen een deel van hun maandgeld uit te betalen. Hierdoor zal zijn rekening te Bordeaux hoger oplopen dan normaal ${ }^{65}$.

De terugtocht kon een aanvang nemen met alle ongemakken van dien: het wachten op een gunstige wind, het wachten op konvooi en het gevaar voor kapers of vijandelijke oorlogsschepen.

Looten vertrekt te Bordeaux op 24 januari $1696^{66}$. Op 14 maart laat Van der Haeghe weten dat Looten met andere schepen te Brest ligt „omdat Engelsche en Hollandtsche oorloghscheepen voor Calais liggen, alwaer sij de passagie hebben gestopt " ${ }^{67}$. Engelse en Hollandse oorlogsschepen, respektievelijk onder bevel van Edward Russell en Gerard Callenberg, waren inderdaad samengetrokken voor Grevelingen wegens verontrustende berichten over Franse troepenbewegingen in de havens Calais en Duinkerke. Was er een landing in Engeland of in Zeeland op til ? Intussen ontdekte men in Engeland het komplot van de hertog van Berwick. Deze wachtte op koning Jacobus, die met een Frans leger op komst was, zodat dit in ieder geval de aanwezigheid van de vloot in het Kanaal rechtvaardigde ${ }^{68}$. Berichten over deze vijande-

Priem, Herman Delffgauw, Pieter Corselis, Bartholomeus Pluvier de jonge, Van Hooghenacker en Bisthoven, Bruyn en Stuyck, Robertus Contales, William Goold. De 25 vat voor rekening van de reders werden bij dezelfde Sauvage gekocht volgens rekening van 21 januari 1696 (Ibidem, 5893), terwijl de 20 vat bestemd voor Vleeschouwer en Priem aangekocht werden door Pierre Bruneau te Bordeaux volgens rekening van 17 januari 1696 (Ibidem, 5896).

65. Looten aan Vleeschouwer, 22 januari 1696 (Ibidem, 5883).

66. Pierre Bruneau aan Vleeschouwer, Bordeaux 24 januari 1696 (Ibidem, 5896) ; Van der Haeghe meent dat Looten wegens tegenwind nog steeds te Bordeaux ligt, 18 februari 1696 (Ibidem, 5888).

67. Van der Haeghe aan Vleeschouwer, Duinkerke 14 maart 1696 (Ibidem, 5888).

68. F.J.G. Ten Raa, Het Staatsche Leger, 1568-1795, 's Gravenhage, VII, blz. 117-118; J. Burchett, Mémoires de tout ce qui s'est passé de plus considérables durant la guerre avec la France depuis l'an 1688 jusqu'd la fin de 1697, (Amsterdam, 1704), blz. 292-315; J.C. Mollema, Geschiedenis van Nederland ter zee, Amsterdam, 
lijke (Looten voer tot Duinkerke met een frans paspoort) vlootbeweging waren ook tot Middelburg doorgedrongen, want op 10 maart vraagt Roelens of hij de lading moet verzekeren: „Looten voor geen capers bevrest en moet wesen, dat seer wel is, ten waer datter een esquader 15 à 16 oorlogschepen rescontrerde. Dito rijsco stater nu voor de hant alsoo de oorlogschepen moeten cruijsen met dese tijdinge uut Engelant alsoo der 40 edeluijden 3 deser den coninck meinde te vermoorden " ${ }^{69}$. De vrees voor verlies zat er zeer sterk in, want op 24 maart dringt Roelens opnieuw aan op verzekeren van schip en lading : "soo d'engelsche blijve crussen voor Dunquerque ofte Grevelingen ofte in Canael. Mijns ordels waere soo goet de noort omme gecomen " 70 . Op 22 maart bereiken Looten en Kettey St.-Malo ${ }^{71}$ en op 18 april Havre-de-Grâce ${ }^{72}$, maar de Engelsen blijven kruisen voor Calais ${ }^{73}$. Nog op 28 april meldt Van der Haeghe: , dan ick en sien geen canse dat sij connen passeeren; de vloote van Brest bestaende in 13 scheepen heeft door eenige engelschen gerescontreert geweest en van de 13 sijnder 11 schepen genomen, waer onder eenige van Oostende" ${ }^{74}$. Ook Roelens drukt zijn vrees uit en dit op 5 mei, waarbij hij niet kan nalaten te wijzen op de kosten van een langdurig wachten : „Verstaen dat schipper Joannes Looten tot Abel

1940-1942, 4 dln, III, blz. 153-155: er werden 20.000 man en 300 transportschepen te Duinkerke samengetrokken met het oog op de invasie van Engeland door koning Jacobus.

69. Roelens aan Vleeschouwer, Middelburg 10 maart 1696 (Ibidem, 5889).

70. Roelens aan Vleeschouwer, Middelburg 24 maart 1696 (Ibidem).

71. Van der Haeghe aan Vleeschouwer, Duinkerke 22 maart 1696 (Ibidem, 5888).

72. Oude benaming voor de stad Le Havre (Dep.: Seine-Inférieure ; arr. : Le Havre).

73. Van der Haeghe aan Vleeschouwer, Duinkerke 18 april 1696 (Ibidem, 5888).

74. Van der Haeghe aan Vleeschouwer, Duinkerke 28 april 1696 (Ibidem, 5888). Jozef de Coninck uit Antwerpen wenst Vleeschouwer op 27 april 1696 geluk dat hij geen belangen had in de gekaapte Oostendse schepen, gezien hij geen handel op Spanje dreef (RAB, Npt, 5887). 
de Grace legt, dat can de heele somer dueren. Hadde beter gedaen de noort omme te loopen, waere al lange thuijs " 75 . Op 8 mei doet Looten een poging om Duinkerke te bereiken met het eskader van Pledts, doch moet onverrichterzake terugkeren ${ }^{76}$. Ook op het lokale vlak werden de moeilijkheden onderzocht ten einde de schepen veilig thuis te krijgen. Pieter Willaert, een geinteresseerde Brugse reder-koopman, vraagt op 10 mei aan Vleeschouwer: "...en de te meer verstaen wij dat voor Ul stadt souden cruijsen acht Staete schepen, de welcke om lootsen bij Ul sijn ghekommen, ja meer dat sij noch eenichte lichte fregatten waeren verwachtende om binnen de bancken te cruijsen op onse schepen ", terwijl hij op 13 mei schrijft : "Ick meijnen over te commen ghedeputert om met de vrijenden te aboucheren en de te sijen of dat wij nijet een middel en souden connen vijnden om onse schepen met een ghevoughelicken en de ghesurghereerde promissij die thuijs te krijghen, maer daer sal wat gheel bij wesen. Daerom moeten wij noch hebben de naemen van de schepen en de schepers mede daer ontrent de quantiteijt van de laedinghe. Wij vergaederen ten neghen uren om te resolveren..." 77 .

De Vlaamse reders zijn er in gelukt een of ander middel te vinden om hun schepen door de kruisende vloot te

75. Roelens aan Vleeschouwer, Middelburg 5 mei 1696 (Ibidem, $5889)$; reeds op 7 april had Roelens op het grote risiko gewezen: «Sien voorder dat schipper Joannes Looten stont met convoy naer Abel de Grace te vertrecken; als daer is sal geerne vernemen. tSal lange reijse maecken soot hem laet aensien met dat den somer op handen is en de vloote van ons niet lichte sal vertrecken. Gelove datse de transportschepen, die voor Calis liggen sullen trachten te bombarderen. tLoopt mede sin perickel tot Abel de Grace ten sij datse daer voor tbombarderen bevrijt waeren » (Ibidem). De «noortomme " vaart was de reisweg die genomen werden door de Engelse en Hollandse schepen bij hun terugkeer uit Oost-Indië, zie de kaart bij R. Davis, The rise... kaart tegenover blz. 318.

76. Looten aan Vleeschouwer, 10 mei 1696 (RAB, Npt, 5883).

77. Pieter Willaert aan Vleeschouwer, Brugge 10 en 13 mei 1696 (Ibidem, 5878). Er komt duidelijk tot uiting dat de Hollandse oorlogschepen speciale opdracht hadden tot het belemmeren van de Vlaamse schepen bij hun terugkeer uit Frankrijk. 
loodsen. Looten zeilt immers rond 18 mei Oostende binnen na een reis van circa vier maanden en bereikt op 31 mei Brugge, waar het grootste deel van de wijnen ontladen wordt ${ }^{78}$.

Van der Haeghe had intussen Vleeschouwer op het hart gedrukt dat de wijn aangekocht voor rekening van de reders onmiddellijk moest verkocht worden, "want het is het sleghste saizoen van het jaer en de risque is veel grooter" 79 . Het was jammer genoeg een desillusie. De wijn kon niet verkocht worden, maar moest gekelderd, "twelck voor ons een groote schaade is, wandt nu met het arrivement van de vloote soo sal dito wijn onvercoopelick weesen" ${ }^{80}$. Jan Priem te Brugge zal zich met de verkoop van de wijn bezig houden alsook met het ophalen van de vrachtgelden ${ }^{81}$. Het zal echter tot oogst 1697 aanslepen ${ }^{82}$, vooraleer een volledige afrekening tot stand komt. Roelens vindt deze late afhandeling ongewoon en fulmineert: „Zien dat een effen rekeninghe hebt gemaekt met monsr Priem van de ontfangen vregten Joannes Looten, dat vrij langh genouch heeft aengeloopen. Als de Bruggelingen met mijn van doen hadden, sou hun goet van de blauwen steen niet laeten volgen voor datse de vregt betaelt saude hebben " 83 .

Het resultaat van deze eerste reis was een inkomen van $16.295 \mathrm{fl}$. courant, samengesteld uit de netto-vrachtgelden en de verkoop van de vis en kolen te Duinkerke.

78. Voor de datum van 18 mei te Oostende zijn we aangewezen op het dokument dat een detail van de volledige lading geeft en gedateerd is Oostende 18 mei 1696 (RAB, Npt, 5896). Van der Haeghe schreef aan Vleeschouwer dat Looten Duinkerke verliet op 18 mei 's morgens vroeg (Ibidem, 5888).

79. Van der Haeghe aan Vleeschouwer, Duinkerke 23 mei 1696 (Ibidem).

80. Van der Haeghe aan Vleeschouwer, Duinkerke 16 juni 1696 (Ibidem).

81. Rekening-kourant van Jan Priem met Vleeschouwer (Ibidem, 5878).

82. Roelens meldt aan Vleeschouwer op 24 oogst 1697 de ontvangst van twee wisselbrieven voor zijn $1 / 16$ deel in de winst van het schip de «St Fransois » (Ibidem, 5889).

83. Roelens aan Vleeschouwer, Middelburg 22 juni 1697 (Ibidem). 
Daarbij komt nog een bedrag van 5.256 fl. ct. voor de verkoop van de wijn, aangekocht voor eigen rekening en door Priem te Brugge verkocht ${ }^{84}$.

Vooraleer het financieel resultaat van deze eerste reis af te wegen, moet de tweede Bordeaux-reis onderzocht worden. De afrekening van oogst 1697 houdt immers rekening met beide tochten.

2.

De tweede reis volgt hetzelfde patroon. Over de bestemming van het schip wordt wel geredetwist. Roelens stelt voor: Bordeaux, of de Kanarische Eilanden, doch heeft geen belangstelling voor de formule half kaapvaart, half koopvaardij ${ }^{85}$. Van der Haeghe is eveneens geneigd Looten naar Bordeaux te zenden, maar merkt op dat de toestand momenteel zeer eigenaardig is : "Boven dien de Hollanders sullen alles doen opcoopen, vermits d'Heeren Staaten van Hollandt geresolveert hebben van hunnen onderdaanen te laten vaaren met paspoort nietjegenstaende de oppositien gedaan van wegens de Keijser, de Coninck van Spagnie en de Prince van Oragnie, twelcke eene vremde speculatie geeft en ijder een doet gelooven dat de Vreede tusschen Vranckericke en Hollandt al beslooten is " 86 .

Uiteindelijk wordt geopteerd voor Bordeaux.

Reeds in juli 1696 werd een paspoort aangevraagd te Brussel of beter gezegd een wijziging van een bestaand paspoort op naam van Jan Looten voor een schip de „St

84. Ibidem, 4866 bis.

85. Roelens aan Vleeschouwer, Middelburg 25 oogst 1696 (Ibidem, 5889) : "Wat min belangt, ick hebben mede geen inclinatie tot cap. Can, Godt danck, leven sonder imants gelt te nemen en de mensche te doen doot schijeten ».

86. Van der Haeghe aan Vleeschouwer, Duinkerke 25 juli en 26 september 1696 (RAB, Npt, 5888). De preliminaire voetstappen voor een algemene vrede waren reeds in maart 1696 gezet met o.m. een herstel van de handel tussen Frankrijk en Engeland op 1 oktober 1696 ( $\mathrm{H}$. Lonchay, $L_{a}$ rivalité de la France et de l'Espagne aux Pays-Bas, 1635-1700, in Mémoires couronnés et autres mémoires publiés par l'Académie Royale de Belgique, LIV (1896), blz. 331-335). 
Jan ", groot 50 vat en afgeleverd op 14 december $1695^{87}$. Op 24 oogst 1696 vraagt de Raad van Financiën advies aan het douanekantoor te Oostende ${ }^{88}$. De zaak vlot jammer genoeg niet. Er zijn moeilijkheden. Het blijkt dat Maximiliaan-Emmanuel onder Engelse en Hollandse druk opnieuw geen paspoorten wil verschaffen voor de handel op Frankrijk ${ }^{89}$. Er wordt hard gewerkt. Van der Haeghe schrijft op 24 november dat een vriend uit Gent hem verzekerde dat Bergeyck aldaar aangekomen was en opnieuw paspoorten zou afleveren ${ }^{90}$. Met kunst en vliegwerk werd de mutatie verkregen ${ }^{91}$.

87. Brussel, Alg. Rijksarchief, Admiraliteit, 575. Bij de registratie te Oostende op 30 december 1695 bleef Salvador de la Feria, waarmede Vleeschouwer een uitgebreide zakenrelatie had (cfr RAB, Npt, 5864 ), borg voor de 6000 gulden. Een kopie van het paspoort is gevoegd bij het rekest (Ibidem, 4866 bis). Het rekest werd door Pieter Broeck rond 13 oogst 1696 ingediend (Ibidem, 5867).

88. Het rekest verzoekt om verlenging en wijziging: «Remonstre tres humblement Jean Looten de Nieuport, maistre sur le navire nommé St Jean, du port de 150 vat, que le $14^{\mathrm{e}}$ de decembre 1694 , il a obtenu de S.A.E. le pasport ci-ioint, au quel par abus l'on n'a mis pour grandeur que 50 vat au lieu de 150 vat, a quoy le remonstrant n'a pas pris esgard en ce temps la, a raison qu'il n'avoit lors encor l'occasion de s'en servir ». Dit rekest werd door Bergeyck geapostilleerd op 24 oogst 1696 (Ibidem, 5866 bis).

89. Van der Haeghe schrijft op 25 juli 1696 : « Als oock dat UE naer Brussel hebt geschreven nopende het paspoort van schipper Looten. Can dat succedeeren, dat is voor ons een groote advantagie Ick en twiffele niet ofte UE sult het vercrigen wanneer door een persoon van caliteijt geappuyeert wort, wandt het paspoort in sijn selven is goedt, hebbende geexpedieert geweest voor den tijdt van het verbodt van comercie. Sijn Hoogheyt can dat toe staen zonder consequentie » (Ibidem, 5888).

90. Van der Haeghe aan Vleeschouwer, Duinkerke 24 november 1696. Het franse paspoort voor Looten was reeds op 19 september in het bezit van Van der Haeghe (Ibidem). Het Spaans paspoort werd vermoedelijk niet vóór 11 januari 1697 verkregen. Pieter Broeck schrijft op deze datum uit Brussel aan Vleeschouwer : «Desen dient om UE te laeten weeten als dat de paspoorten beginnen te faciliteren en de men begint permissien te accorderen om met de oude paspoorten te gaen nae Vranckrijck wijnen halen, mits de selve niet gedient en hebben. Ick hebbe soo over twee daegen eene becommen voor een coopman van Brugge. En de de medegaende permissie hebbe ick becomen voor mijnheer Lafranco den 5 deser. In cas UE noch eenige oude paspoorten hebt, men soude oock wel eene permissie becomen " (Ibidem, 5867).

91. Er was inderdaad een «persoon van caliteijt» nodig. De on- 
Ondertussen had Looten niet gewacht. Op 16 oogst betrok hij zijn schip voor een nodige revisie ${ }^{92}$ en gezien het nieuwe paspoort op zich liet wachten, raadde Van der Haeghe aan hem zonder verwijl met het oude paspoort te laten uitzeilen ${ }^{93}$.

Looten vertrekt op 20 oktober te Oostende en komt op 29 oktober op de rede van Bordeaux ${ }^{94}$.

Op dat ogenblik was de markt van de vrachtprijzen nog onvast. Er lagen drie fregatten, waarvan de lading voor eigen rekening gebeurde ${ }^{95}$. Laurens Reuben, die ongeveer rond hetzelfde tijdstip als Looten te Bordeaux aankwam, bedong een vrachtprijs van $110 \mathrm{fl}$. wisselgeld ${ }^{9}$. Looten daarentegen verkreeg $118 \mathrm{fl}$. wisselgeld, misschien omwille van de klaarblijkelijke voordelen die zijn schip bood en waarvan reeds tijdens de eerste reis melding werd gemaakt. Toen reeds 60 vat gekontrakteerd was, werd plots het bestaan van het oude paspoort bekend. Pieter Corselis, een Nieuwpoortse reder-koopman, had dit aan de kooplieden van Bordeaux meegedeeld, zodat de bevrachters

kostenrekening van het schip vermeldt: «Over de oncosten tot Brussel betaelt aen den soliciteur Pieter Brouck tot becomen de veranderinghe van het spaens paspoort in Augustus 1696, maer naer alle ghedaen devoir door die wegh niet connen obtineren $»$, zodat een supplementaire uitgave van $292 \mathrm{fl}$. (1 stuk wijn te Oostende en $11 / 2$ stuk wijn te Brussel) nodig was: «gegeven aen persoonen dienst gedaen hebbende om tschip en laedinghe te bevrijden met het oude paspoort van 50 vat » (Ibidem, 4866 bis). Pieter Broeck uit Brussel spreekt van de hulp van auditeur Remy (Ibidem, 5867).

92. De loonlijst vermeldt Looten vanaf 16 oogst 1696 (Ibidem, 4866 bis).

93. Van der Haeghe aan Vleeschouwer, Duinkerke 20 oktober 1696: "Sijne Hoogheyt wederom refuseert paspoorten te geven, door reden dat Engelant en Hollant daer heel tegen is. Daerom soo Joannes Looten noch niet vertrocken is, laet hem ten eersten met sijn oudt paspoort vertrecken » (Ibidem, 5888).

94. Ibidem, 4866 bis ; Looten aan Vleeschouwer, 3 november 1696 (Ibidem, 5883).

95. Ibidem.

96. Looten aan Vleeschouwer, 27 november 1696 (Ibidem, 5883). Laurens Reuben voerde het fregat de «St Anna », groot 50 vat, waarvoor een paspoort op 19 oktober 1695 verkregen werd (Brussel, Alg. Rijksarchief, Admiraliteit, 575). Over dit schip in 1697, zie RAB, Npt, 4866 bis. 
terugschrokken. De firma wed. Clock en zoon te Bordeaux, die handelde in opdracht van Vleeschouwer, durfde het niet aan op eigen risiko de kooplieden te verzekeren dat hun goederen bij aankomst te Oostende niet zouden aangeslagen worden ${ }^{97}$. Dit bleef zo duren tot Vleeschouwer een schriftelijke opdracht zond aan de firma Clock. Deze bleef uiteindelijk borg voor 14 vat wijn van de firma Van den Brande ${ }^{98}$.

Kostbare tijd was echter verstreken en Lootens vrachtprijs gedaald tot $110 \mathrm{fl}$. per vat ${ }^{99}$. Zonder verdere hindernissen bereikte hij tegen einde december 1696 zijn volle lading (168 vat), waaronder 10 vat op half-winst van de handelaar Martinus Hagens ${ }^{100}$. Hij vertrekt op 6 januari 1697 en arriveert op 14 februari te Oostende na diverse Franse havens te hebben aangedaan om proviand, nl. La Rochelle, Camaret-sur-Mer en Landerneau ${ }^{101}$. Het grootste deel van de bemanning wordt afgedankt met uitzondering van degenen nodig voor bewaking en ontlading. Op 16 maart 1697 was alles gelost te Brugge, op 2 vat wijn na, bestemd voor Oostende. Van de bemanning blijven nu alleen 2 man en 1 jongen ${ }^{102}$. Jan Priem heeft opnieuw

97. Looten aan Vleeschouwer, 27 november 1695 (Ibidem, 5883). Van der Haeghe behandelt hetzelfde probleem in zijn brief van 5 december 1696 (Ibidem, 5888).

98. Akte verleden voor de notaris Lemoine te Bordeaux op 14 december 1696 (Ibidem, 4866 bis) ; weduwe Clock aan Vleeschouwer, Bordeaux 18 december 1696 (Ibidem, 5897).

99. Looten aan Vleeschouwer, 27 november 1696 (Ibidem, 5883). Ook het schip de «Hertog van Beieren » en Frans Snoeck bedongen een vrachtprijs van 110 gulden wisselgeld per vat. Bruneau aan Vleeschouwer, Bordeaux, 29 december 1696 en 8 januari 1697 (Ibidem, 5896).

100. Volgende kooplieden van Bordeaux hadden de $1661 / 6$ vat wijn geladen in het schip van Looten: Cornelis Delffgauw, Besson, Denis, Brunnaud, Walsch, Hendricq Lutkens, Martinus Hagens, Philippe van den Brande, Jasper Pett, weduwe Clock. De tien vat geladen op half-winst met M. Hagens werden door Jan Priem te Brugge verkocht op 10 maart 1697 (Ibidem, 4866 bis).

101. Ibidem, 4866 bis ; Camaret-sur-Mer (Dep. Finistère, arr. Châteaulin); Landerneau (Dep. Finistère, arr. Brest).

102. Looten aan Vleeschouwer, 16 maart 1697 (Ibidem, 5883). 
de leiding van de verkoop van de wijn op half-winst en de inzameling van de vrachtgelden. De afrekening gebeurt samen met deze van de eerste tocht. De onkosten van de tweede Bordeaux-reis beliepen $10.110 \mathrm{fl}$. courant en de bruto-inkomsten 20.312 fl. ct., zodat er een batig saldo bleef van $10.202 \mathrm{fl}$. ct. ${ }^{103}$.

\section{3.}

Hoewel de derde reis van de hoeker voor ons van minder nut is - ten andere de financiële gegevens hierover zijn uiterst sommair - is hij toch niet van alle belang ontbloot en wel om de duidelijke tegenstelling met de vorige. Deze derde tocht verloopt immers op een ogenblik dat de Vrede van Rijswijk reeds gesloten is (20 september 1697) en aldus een einde heeft gesteld aan de Negenjarige Oorlog.

De ophanden zijnde vrede werd reeds lang aangevoeld in handelsmiddens en had er een duidelijke weerslag op. In februari 1697 zijn er berichten uit Bordeaux dat de vrachtprijzen gedaald zijn tot 48 à $50 \mathrm{fl}$., terwijl de bestellingen uit Vlaanderen zeer schaars zijn ${ }^{104}$. In april-juni geschiedt de bevrachting grotendeels op half-winst basis; dit is bv. het geval met Jacob de Wymer, Pieter Winnaert, Cornelis Valckenier, Thomas Bekue, terwijl de vracht schommelt tussen 32 en $45 \mathrm{fl}{ }^{105}$.

In september laat Roelens een gunstig geluid horen : "Ick sau van advijs wesen tschip St Frans claer te maecken om naer Bordeaux te vaeren, daer tseer bequaem toe is. tSal genouch sijn vregt crigen op deen platse ofte dander. De vrinden alhier presenteren te laeden voor $60 \mathrm{fl}$. tvatt

103. Ibidem, 4866 bis.

104. Bruneau aan Vleeschouwer, Bordeaux 2 februari 1697 : "Nooyt binnen d'orders van costy soo schrael geweest " (Ibidem, 5896).

105. Bruneau aan Vleeschouwer, Bordeaux 27 april en 12 juli 1697 (Ibidem). 
om dat hier aan den vrede niet en wordt getwyffelt; maecken staet dat die in corte dagen sal geteeckent worden". De door Roelens geopperde belangstelling van de Hollanders voor een rechtstreekse aanvoer van Franse wijn - mogelijk gemaakt door het aanstaande vredesverdrag was voor de Vlamingen geen geheim. Zij zouden trachten de Hollanders voor te zijn ${ }^{106}$.

Op 1 september trekt Looten aan boord voor nazicht. Het groot want moest immers vervangen worden, wat niet belet dat hij op 30 september te Oostende zeilree ligt ${ }^{107}$ en op 5 oktober naar Bordeaux vertrekt om daar in gezelschap van een antal andere Vlaamse schepen op 14 oktober aan te leggen ${ }^{108}$.

Het is voor Looten onmiddellijk duidelijk dat het optimisme van Roelens geen grond raakt. De lading zal een probleem worden; vrachten op Amsterdam bv. lopen van 15 tot $23 \mathrm{fl}$. ,Hier heeft men een dieppois op $20 \mathrm{fl}$. al bevragt en men zoude verscheijde andere op tzelve voet, ja oock betercoop hier cunnen bevinden", zo schrijft Pierre Bruneau uit Bordeaux en Looten voegt er bitter aan toe "datter soo veele scheepen sijn, die het sullen voeren voor 15 gulden per vadt, soo is het beeter dat men mij ten eerste voort helpt. Men moet op geen vrecht betrauwen" 109 .

$\mathrm{Bij}$ het vernemen van dit nieuws, besluiten de reders - indien geen voordelige vracht kan bekomen worden het schip voor eigen rekening te laden met bestemming Rotterdam. De berichten uit Amsterdam en Rotterdam

106. Roelens aan Vleeschouwer, Middelburg 7 september 1697 (Ibidem, 5889).

107. Looten aan Vleeschouwer, 2 september 1697 (Ibidem, 5883).

108. Jan Priem aan C.F. de Pouillon te Gent, Brugge 8 oktober 1697 : «Joannes Looten, Lauwerens Reuben en Pieter Valckenier en Cornelis Vermeulen sijn op den 5 deser per Bordeaux vertrocken » (Gent, Rijksarchief, Raad van Vlaanderen, $1^{\text {e }}$ reeks, 3955); Looten aan Vleeschouwer, 15 oktober 1697 (RAB, Npt, 5883).

109. Looten aan Vleeschouwer, 15 oktober 1697 (Ibidem, 5883); Bruneau aan Vleeschouwer, 15 oktober 1697 (Ibidem, 5896). 
zijn immers unaniem : „Hier konden de wijnnen heel wat gelden en hier mogen se nu vrij incomen" 110 . Te Brugge is de nieuwe wijn onverkoopbaar ${ }^{111}$.

Roelens vindt het een goede oplossing: „Tijs wel tgeene UE met de redders hebt geresolveert, soo hij met sijn arrivement geen goede vraght voorvalt, geresolveert hebt groote partie voor tschipsrekeningh te ordonneren goede mostighe cruijden. Die sijn hier gelt wert en dat UE hem hier naer toe sult laeten comen om deeste te wesen, die met nieuwe vruchten sal arriveren, dat al wel is. Daer sin van hier noch geen schepen naar Vranckrick vertrocken. Daer sin 2 schepkens die claer maecken om daer naer toe te gaen " 112 .

Het lang uitblijven van deze beslissing om voor eigen rekening 80 vat wijn en 60 stukken pruimen te laden op Rotterdam, heeft Looten enkele goede kansen doen missen. Intussen zijn er wel 25 hollandse en zeeuwse schepen aangekomen "dije deeden de vrechten daelen" ${ }^{113}$. Ook Roelens schrijft dat er reeds circa 20 oktober 10 à 12 schepen uit Vlissingen zijn vertrokken met bestemming Bordeaux ${ }^{114}$. Het oorspronkelijk projekt dat Looten tegen 10 november zijn volle vracht zou hebben, valt falikant uit. Dit gebeurde eerst tegen 23 november en hij zal slechts op 3 december zeilree zijn. Dit uitstel zal nadelig uitvallen voor de reders of zoals Roelens beweert: „Dat Looten daer soo lange moet blijven liggen, dat seer grooten intrest is voor de reeders. Deeste schepen, die met nieuwe

110. Willem van Nes van Amsterdam aan C.F. de Pouillon te Gent, 24 oktober 1697; Jacob Houtman van Rotterdam aan dezelfde, 25 oktober 1697 (Gent, Rijksarchief, Raad van Vlaanderen, $1^{\circ}$ reeks, 3955).

111. Jan Priem van Brugge aan C.F. de Pouillon, 26 oktober 1697 (Ibidem).

112. Roelens aan Vleeschouwer, Middelburg 12 oktober 1697 (RAB, Npt, 5889).

113. Looten aan Vleeschouwer, 23 november 1697 (Ibidem, 5883).

114. Roelens aan Vleeschouwer, Middelburg 2 november 1697 (Ibidem, 5889). 
wijnen sullen comen, sullen wel slaen, want ider roept hier om nieuwe wijn" 115 .

Lootens lading bestaat nu uit $131 \frac{1}{2}$ vat wijn en 144 stukken pruimen à rato van 4 stukken per vat, wat een totaal van $1671 / 2$ vat geeft ${ }^{116}$. Hiervan zijn 80 vat wijn en 60 stukken pruimen voor eigen rekening. De rest is vracht à $20 \mathrm{fl}$. wisselgeld per vat ${ }^{117}$, waarover Roelens duidelijk zijn ongenoegen te kennen geeft : „Dat is een groote misslach voor $20 \mathrm{fl}$. te vrechte te laeden. Sau meer contentement daer in hebben dat hij voor de reeders heel hadden gelaeden ", en verder : "Ben moyelick in mijnen geest, dat gie toe hebt gestaen dat ons schip te vrechte gaet laeden op $20 \mathrm{fl}$. per vat. UE hebt voor eeter vier geseten. De reeders moeten bange wesen". Intussen zal Roelens trachten 3 à 400 pond groot op schip en lading te verzekeren à rato van 3 à $3 \frac{1}{2} \%$. Er zijn echter moeilijkheden, gezien de voortdurende aktiviteit van de Biskaaise kapers ${ }^{118}$.

De terugreis van Looten loopt niet van een leien dakje. Geplaagd door kontinueel stormweer, mist en sneeuwbuien, drijft het schip uit zijn koers en strandt op de zuidkust van Engeland nabij Shoreham. Het kostte heel wat geld om het opnieuw vlot te krijgen en met een oostenwind de franse kust te bereiken. Op 29 januari 1698 ligt hij voor Calais en gaat voor anker te Ambleteuse ${ }^{119}$. Bij zijn ankomst te Duinkerke op 8 februari is de tocht nog niet ten einde. Naast een verlies van tijd

115. Roelens aan Vleeschouwer, Middelburg 15 november 1697 (Ibidem).

116. Looten klaagt er over dat men te Bordeaux 4 stukken pruimen rekent voor één vat, wat met een gewicht van 3.000 pond overeenstemt, Looten aan Vleeschouwer, 23 november 1697 (Ibidem, 5883). De weduwe Clock schreef daarentegen aan Guillaume Looten op 22 oktober 1695 dat 1 stuk pruimen ongeveer 1.000 à 1.100 pond woog en dat 2 stukken gerekend werden voor één vat (Ibidem, 5461).

117. Looten aan Vleeschouwer, 23 november 1697 (Ibidem, 5883).

118. Roelens aan Vleeschouwer, Middelburg, 8 en 14 december 1697 (Ibidem, 5889).

119. Looten zendt op 30 januari 1698 een kompleet verslag van 
te Duinkerke als gevolg van moeilijkheden met de bemanning ${ }^{120}$, komt hij op 24 februari 1698 voor Vlaardingen in het ijs te zitten ${ }^{121}$, iets waarvoor Roelens reeds in december 1697 gewaarschuwd had ${ }^{122}$. Het duurt nog tot 3 maart eer hij te Rotterdam voet aan wal zet. Hij is buiten tijd om nog een goede marktprijs voor wijn en pruimen te kunnen bedingen. Reeds op 10 januari 1698 had de Rotterdamse firma Valck en Leuven aan Vleesschouwer geschreven dat "ondertusschen soo sijn de wijnen hier stijf overvolct en sijn hier de heele weeck deur alle avonde 5 à 6 verkoopinge " ${ }^{123}$, en op 17 januari laat dezelfde firma weten nopens de verkoop van de wijn gekomen met het schip de "St Anna " van Jacob de Wymer : „Had die wijn van UL ter behoorelijker tijd hier geweest, het soude seer veel in de prijs gescheelt hebben, dog men kan niet meer als sijn devoir doen. Gods weer en wint heeft de selvige soo lange doen trayneeren" ${ }^{124}$. En het zou nog meer dan één maand duren eer Looten aankwam.

De firma Valck en Leuven te Rotterdam verkocht de wijn en de pruimen en zamelde de vrachtgelden in.

Er is nog één detail van deze reis bekend. Het eindresultaat was een batig saldo van $7.16 .0 \mathrm{fl}$. ct., waarin

zijn reis aan Vleeschouwer (Ibidem, 5883). De onkosten van het stranden te Shoreham (Engeland, co. Sussex) waren hoog «wandt de steenen in dat landt hebben ons geldt gevracht ». De brief van 30 januari werd geschreven te "Reede Abel Teeuse of ander St Jan » nl. te Ambleteuse (Dep. Pas-de-Calais, arr. Boulogne-sur-Mer).

120. Looten aan Vleeschouwer, 8 februari 1698 (Ibidem, 5883).

121. Looten aan Vleeschouwer, 3 maart 1698 (Ibidem, 5883).

122. Roelens aan Vleeschouwer, Middelburg 21 december 1697 (Ibidem, 5889) : « ...moet niet zo jagen, alsoo hij de Mase niet sal connen aendoen over den swaren isganck die der sal gaen ». De harde en lange winter van 1697/98, zoals meegedeeld door Looten, kadert zeer goed in het resultaat van het werk van E. Le Roy Ladurie, Histoire du climat..., blz. 54: "On ne trouve réellement une série noire d'années très froides qu'à l'extrême fin du XVII ${ }^{\circ}$ siècle entre 1687 et $1704 »$.

123. Valck en Leuven aan Vleeschouwer, Rotterdam 10 januari 1698 (RAB, Npt, 5900).

124. Valck en Leuven aan Vleeschouwer, Rotterdam 17 januari 1698 (Ibidem). 
ook de onkosten van het stranden te Shoreham zijn verrekend ${ }^{125}$.

Hiermede lag Looten met zijn hoeker te Rotterdam. De schade aan het schip, veroorzaakt door de stranding, was minder erg dan gevreesd. Daarentegen was er een volstrekte onmogelijkheid om voor het schip een lading te krijgen bestemd voor Lissabon, de Kanarische Eilanden of Porto ${ }^{126}$. Ook Marseille bood geen uitkomst gezien er te Amsterdam twee schepen met ieder 30 stukken geschut te vracht lagen ${ }^{127}$. Er was een kans het schip te verkopen voor 8.000 gulden, doch het schip zou een beetje moeten gekalfaat worden ${ }^{128}$. Er is diskussie tussen de reders. Vleeschouwer is wel geneigd te verkopen. Van der Haeghe en zijn Duinkerkse vrienden willen het schip naar Bordeaux, Bayonne of La Rochelle zenden. Van der Haeghe stelt zelfs voor Vleeschouwers andeel in de hoeker te ruilen voor zijn $1 / 8$ deel in het schip van Frans Snoeck ${ }^{129}$. Onderwijl is Looten bezig de nodige herstellingswerken uit te voeren.

De uiteindelijke beslissing was verkoop van de hoeker samen met het katschip van Jacob de Wymer, dat meer dan één maand vroeger dan Looten te Rotterdam was aangekomen. De beslissing betreffende het katschip werd genomen te Nieuwpoort op 8 mei $1698^{130}$. Wat betreft de hoeker is het wel eigenaardig dat de boedel van Guillaume Looten, die in de hoeker geïnteresseerd was, eveneens op 8 mei 1698 gekrediteerd werd voor 1/16 van de verkoop ervan $\mathrm{nl} .8 .000$ gulden hollands. Beide schepen schijnen dus rond hetzelfde tijdstip verkocht te zijn $^{131}$.

125. Ibidem, 4866 bis.

126. Looten aan Vleeschouwer, 18 maart 1698 (Ibidem, 5883).

127. Looten aan Vleeschouwer, 11 april 1698 (Ibidem, 5883).

128. Looten aan Vleeschouwer, 18 maart 1698 (Ibidem).

129. Van der Haeghe aan Vleeschouwer, Duinkerke 25 maart 1698 (Ibidem, 5888) ; Roelens was ook bereid tot verkoop, cfr Roelens aan Vleeschouwer op 15 februari 1698 (Ibidem, 5889).

130. Ibidem, 5900.

131. Ibidem, 5893. 
Hiermee was de odyssea van de hoeker „St Fransois / St Jan" ten einde.

4.

De winst gerealiseerd door deze hoeker tussen november 1695 en mei 1698 is daarmee niet opgehelderd.

1. De eenvoudige boekhouding van Vleeschouwer, die in juni 1697 de eerste twee reizen van de hoeker besloot met de woorden : „Dus kompt den voors. schepe a saldo deser boni, boven dat ditto schip suijver is inghewonnen, noch 13.614.8.4 fl. ct." kan als basis gebruikt worden, doch geeft een bedrieglijk beeld van de netto-winst ${ }^{132}$.

Prof. Davis wees er op dat de 17 eeuwse reders een aantal elementen die momenteel een integraal deel uitmaken van de scheepsboekhouding, niet in aanmerking namen. Hieronder verstaat hij de depreciatie van het schip of de jaarlijkse afschrijving op de scheepswaarde en de intrest van het kapitaal, dat aan uitreding moet besteed worden. Over dit kapitaal zal de reder slechts kunnen beschikken na de terugkeer van het schip, wanneer de vrachtgelden zijn geind en de balans is opgemaakt ${ }^{133}$.

We zullen nu trachten deze diverse elementen, die niet in de 17eeuwse boekhouding zijn opgenomen, op te sporen om aan de hand daarvan een preciezer beeld van de winst te schetsen.

2. De kostprijs van het schip is betrekkelijk duidelijk. Op 1 oktober 1695 kocht Roelens te Vere de hoeker voor 1.351 pond groot. Dit bedrag schijnt onvolledig te zijn. Hoger werd gezegd dat allerlei noodzakelijke elementen, die verdwenen waren, moesten aangekocht worden om het schip zeilwaardig te maken, zodat Roelens Vleeschouwer op 25 oktober 1695 debiteert voor een bedrag van 1.846 pond groot ", voor 't schip Ste Frans".

132. Ibidem, 4866 bis.

133. R. Davis, Earnings of capital in the English shipping industry, 1670-1730, in Journal of Economic History, XVII (1957) blz. 409-425. 
We nemen aan dat dit laatste bedrag de juiste kostprijs van de hoeker inhoudt, nl. $11.950 \mathrm{fl}$. courant ${ }^{134}$.

3. De uitredingskosten vormen een moeilijkheid. Ze zijn wel te berekenen voor de eerste twee reizen, doch voor de derde ontbreekt ieder financieel gegeven. Daarom zullen we ons beperken tot reis 1 en 2 . Ten andere - zoals reeds opgemerkt - de derde tocht heeft voor ons minder belang gezien deze gebeurde in vredestijd.

3a. Konkrete cijfers van uitreding en andere kosten (administratieve, proviandering e.d.) gemaakt tijdens de eerste Bordeaux-reis (oktober 1695 - mei 1696) zijn niet voorhanden. $\mathrm{Zij}$ kunnen nochtans in $\mathrm{min}$ of meerdere mate teruggevonden worden.

In de eerste plaats is er het bedrag van 195 pond groot ( \pm 1.270 fl. ct.), dat Roelens op 5 november 1695 op de debetrekening van Vleeschouwer plaatst "voor gelt en goederen tot behouf van t'schip St Frans" ${ }^{135}$.

3b. Voor de verdere kosten van het tweede deel van deze eerste reis (Duinkerke - Bordeaux - Brugge) moet een kleine berekening gemaakt worden. We vertrekken van het bedrag van $16.295 \mathrm{fl}$. ct. genoteerd door Vleeschouwer als "over het eerste retour vreght en provenu van vercochte coolen en visch". Volgens een losse nota van Vleeschouwer in het dossier, bedroeg de netto opbrengst van voornoemde kolen en vis $7.650 \mathrm{fl}$. ct. ${ }^{136}$. Het verschil tussen beide cijfers nl. $16.295-7.650=8.645$ fl. ct. geeft de netto-opbrengst van de vrachtgelden, waarvan afgetrokken de diverse kosten opgelopen tijdens deze reis.

3c. De bruto-vrachtgelden kunnen bij benadering opgezocht worden. Het schip had een volle lading, dus 168 vat à 100 gl. wisselgeld per vat. Van deze 168 vat moet

134. Roelens aan Vleeschouwer, 1 oktober 1695 ; Rekening-kourant van Roelens met Vleeschouwer, 1695 (RAB, Npt, 5889).

135. Ibidem.

136. Ibidem, 4866 bis. 
echter 25 vat afgetrokken worden, gezien deze geladen werden voor eigen rekening. De vracht moet dus - ruw gerekend - ongeveer $14.300 \mathrm{fl}$. wisselgeld of $15.500 \mathrm{fl}$. ct. opgebracht hebben. Daarbij dient nog de averij gevoegd. Gezien er zich geen speciale moeilijkheden hebben voorgedaan, nemen we hetzelfde bedrag dat door de reders voor de tweede reis berekend werd $\mathrm{nl} .500 \mathrm{fl}$. $\mathrm{ct}^{137}$. Het totaal inkomen van de eerste vracht bedroeg dus 16.000 fl. ct. Het verschil tussen deze $16.000 \mathrm{fl}$. en het batig saldo van $8.645 \mathrm{fl}$. (sub 3b) nl. 7.355 fl. ct geeft een eerste beeld van de kosten opgelopen tijdens het tweede deel van de eerste reis. Hierbij moet inderdaad nog een 1.000 pond tourn. gevoegd, die Sauvage aan Looten te Bordeaux heeft uitbetaald en die afzonderlijk (samen met de 25 vat wijn gekocht voor eigen rekening) door Vleeschouwer werd geboekt en betaald ${ }^{138}$. Dit blijkt o.m. uit de boedelrekening van G. Looten, waarbij deze laatste gedebiteerd wordt voor $1 / 16$ van deze rekening. Deze 1.000 pond geven $800 \mathrm{fl}$. $\mathrm{ct}^{139}$, zodat de totale kosten van deze eerste reis bedragen : $7.355+800+1.270$ (sub 3a) $=$ 9.425 fl. ct.

3d. De onkostennota van de tweede reis is veel gedetailleerder en werd door Vleeschouwer zelf berekend aan de hand van de bewijsstukken van het dossier op 10.109 fl. $\mathrm{ct}^{140}$.

3e. Rekapitulatie van het geïnvesteerde kapitaal :

$\begin{array}{lr}\text { Aankoop schip } & 11.950 \mathrm{fl} \text {. ct } \\ \text { Kosten eerste reis } & 9.425 \mathrm{fl} \text {. ct } \\ \text { Kosten tweede reis } & 10.109 \mathrm{fl} \text {. ct }\end{array}$

4. De samenstelling van de bruto-winst moet er onge-

137. Ibidem.

138. Genoteerd op de rekening van H. Sauvage van Bordeaux van 21 januari 1696 (Ibidem, 5893).

139. De omzetting gebeurde volgens de verhouding genomen door Joannes Looten in zijn onkostennota nl. 2093 ponden tourn. $=1813$ gulden courant (Ibidem, 4866 bis).

140. Ibidem. 
veer als volgt uitzien : netto-opbrengst van de vracht van de eerste reis $8.645 \mathrm{fl}$. ct (sub $3 \mathrm{~b}$ ); deze van de tweede reis $10.202 \mathrm{fl}$. ct, volgens opgave van Vleeschouwer. Daarnaast werd nog een winst gerealiseerd op de verkoop van vis en kolen te Duinkerke en op de aanvoer van 25 vat wijn, gekocht voor eigen rekening, te Brugge in mei 1696 . Deze twee laatste posten vergen echter een nader onderzoek.

4a. De aankoop van de kolen bedroeg volgens de opgave van Roelens op 11 november 1695423 pond groot of $\pm 2.700 \mathrm{fl}$. $\mathrm{ct}^{141}$. De kostprijs van de vis is niet voorhanden, doch kan wel geanalyseerd worden uit de voorhanden zijnde totale bedragen. De eerste debetpost van de algemene scheepsrekening beloopt $18.140 \mathrm{fl}$. ct en omvat de aankoop van het schip en de lading $\mathrm{nl}$. vis en kolen ${ }^{142}$. Welnu schip en uitreding hebben gekost 11.950 (sub 2) en $1.270 \mathrm{fl}$. ct (sub 3a), zodat voor de vis en de kolen rest $4.920 \mathrm{fl}$. ct. Netto-opbrengst van deze lading resulteerde in sub $3 \mathrm{~b}$ geciteerde bedrag van $7.650 \mathrm{fl}$. ct, zodat er een winst van $2.730 \mathrm{fl}$. ct werd gemaakt.

4 b. De wijn door H. Sauvage voor de reders aangekocht bedroeg volgens een rekening van 21 januari 16964.260 pond tourn. of $3.400 \mathrm{fl}$. ct. De verkoop ervan te Brugge door Jan Priem gaf een netto-opbrengst te zien van 5.256 fl. ct $^{143}$. Hier was de winst dus : $1.856 \mathrm{fl}$. ct.

4c. Rekapitulatie van de winst :

Netto-vracht eerste reis

8.645 fl. ct

Winst op de wijn

$1.856 \mathrm{fl}$. ct

Winst op vis en kolen

$2.730 \mathrm{fl}$. ct

Netto-vracht tweede reis

$10.202 \mathrm{fl}$. ct

23.433 fl. ct

141. Rekening-kourant van Roelens met Vleeschouwer, 1695 (Ibidem, 5889).

142. Ibidem, 4866 bis.

143. Ibidem. 
5. De periode waarin deze winst verwezenlijkt werd liep van november 1695 tot oogst 1697, datum waarop een eerste afrekening tussen de reders gebeurde volgens een rekening opgemaakt door de boekhouder van het schip, nl. Carel de Vleeschouwer, dus een termijn van 22 maanden. De aandeelhouders konden dus slechts vanaf september 1697 over hun geïnvesteerde kapitalen beschikken. Dit is bv. het geval voor Gillis Roelens, die reeds vanaf 25 oogst 1696 voortdurend geïnsisteerd had op een afrekening.

6. Dit uitblijven van de afrekening is er oorzaak van dat de aandeelhouders gedurende de bovengenoemde termijn van 22 maanden geen beschikking over hun geïnvesteerde kapitalen hadden. Deze niet-beschikking betekende voor de eigenaars een verlies van intrest, die eventueel had kunnen verwezenlijkt worden. $\mathrm{Nu}$ wordt deze intrest door prof. Davis op $5 \%$ geraamd ${ }^{144}$. Indien we dit percentage aanvaarden en toepassen op de door reders belegde kapitalen, komt men tot volgend resultaat :

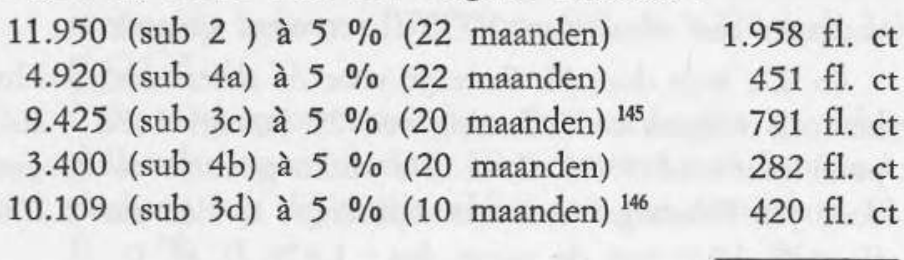

3.902 fl. ct

7. Daarnaast is er nog de depreciatie van het schip. Gebruik en ouderdom verminderde inderdaad de waarde ervan. In dit specifieke geval zal echter ook de veranderde ekonomische konjunktuur nog een rol spelen. Prof. Davis had immers berekend dat met een jaarlijkse waardever-

144. R. Davis, Earnings..., in Journ. Econ. History, XVII (1957), blz. $410-412$.

145. Januari 1696 - oogst 1697.

146. Oktober 1696 - oogst 1697. 
mindering van $4 \%$ moest rekening gehouden worden ${ }^{147}$. In ons geval ligt dit percentage ver beneden de werkelijkheid.

De aankoop bedroeg immers in oktober 169511.950 fl. ct. ; de verkoop in mei 1698 leverde daarentegen slechts $8.230 \mathrm{fl}$. ct op, zodat er een verlies was van $3.720 \mathrm{fl}$. ct in een periode van 30 maanden, wat neerkomt op circa $12 \%$ per jaar. We vermoeden dat de scheepsmarkt hier wel voor een deel toe bijdroeg. Het verlies waarmede we echter moeten rekening houden tijdens de door ons bestudeerde 22 maanden, komt op $2.728 \mathrm{fl}$. ct.

8. Het totaal verlies aan kapitaalintrest en waardevermindering bedroeg aldus : 3.902 (sub 6) +2.728 (sub 7) $=6.630 \mathrm{fl}$. ct.

9. Het verwerken van dit laatste element moet een juist beeld geven van de netto-winst. Aldus wordt van de reeds berekende winst (sub 4c) $23.433 \mathrm{fl}$. ct het sub 8 supplementaire verlies van $6.630 \mathrm{fl}$. ct afgetrokken met als eindresultaat : $16.803 \mathrm{fl}$. ct.

Dit laatste cijfer zou moeten overeenstemmen met de werkelijkheid. Naast een investering van $30.582 \mathrm{fl}$. ct werd een zuivere winst van $16.803 \mathrm{fl}$. ct verwezenlijkt tijdens een termijn van 22 maanden, wat overeenkomt met een jaarlijkse intrest van $28 \%$.

Het ligt voor de hand dat deze winst moeilijk te vergelijken is met de cijfers door prof. Davis bekomen met uitzondering misschien van het resultaat van een 120 ton metend schip ingelegd op Malaga in 1635 ; maar prof. Davis twijfelt aan de juistheid van zijn bevindingen en maakt enig voorbehoud ${ }^{148}$.

147. R. Davis, Earnings..., in Journ. Econ. Hist., XVII (1957), blz. $410-411$.

148. R. Davis, The rise of the English shipping..., blz. 379. Ook te Nantes wordt op het einde van de $18^{\mathrm{e}}$ eeuw een grote verscheidenheid van winstmarges vastgesteld, cfr de winsten van de firma Bouteiller tussen 1752 en 1784 . Er wordt eveneens voorbehoud gemaakt enerzijds wegens de enorme tijdspanne tussen investering 
Het verschil ligt in de abnormale omstandigheden. De reizen van de hoeker ,, St.-Fransois " gebeurden in oorlogstijd met uitzonderlijk hoge vrachtprijzen ( 100 - $110 \mathrm{fl}$. wisselgeld) ${ }^{149}$ als gevolg van de uitschakeling van de konkurrentie en door het vermijden van verzekeringskosten, die op dat ogenblik minstens 20 à $25 \%$ zouden hebben bedragen ${ }^{150}$, en dit door het spelen onder één hoedje met de Fransen. De grote bemanning ( $\pm 30 \mathrm{man}$ ), die circa $1 / 3$ van de lopende kosten opslorpte ${ }^{151}$, maar die - zoals Looten opmerkte - uiteindelijk in het voordeel van het schip zou opereren, kon gemakkelijk gedragen worden. Wanneer men dezelfde hoeker in vredestijd zou inleggen met alle gevolgen van dien $\mathrm{nl}$. moeilijk te krijgen vracht met als gevolg lange wachttijd, lage vrachtprijzen (20 fl. wisselgeld), kleine bemanning ( $\pm 10 \mathrm{man})^{152}$ en lage verzekeringskosten $( \pm 3 \%$ ) dan zou het vermoedelijk resultaat bij een voordelige reis niet hoger liggen dan Davis' cijfers nl. 3 à $4 \%$. Doch voordelige reizen waren problematisch.

$\mathrm{Al}$ met al is het niet te ontkennen dat een dergelijke kans

en afrekening (kan soms 50 jaar duren) en anderzijds omdat de firma Bouteiller ook eigen plantages bezat op San Domingo. Dit laatste speelde in de winstvorming een wezenlijke rol (J. Meyer, L'armement Nantais dans la deuxième moitié du XVIII ${ }^{\circ}$ siècle, Paris, 1969, blz. 239-241).

149. Deze hoge vrachtprijzen gelden niet alleen voor BordeauxBrugge. In 1691 was de vrachtprijs Bayonne-Brugge ook $100 \mathrm{fl}$. per vat (Brussel, Alg. Rijksarchief, Admiraliteit, 527, bundel 50). Voor de tocht Nantes-Brugge is een betrekkelijk volledige reeks voorhanden : 80 à $90 \mathrm{fl}$. (1691); 80 à $90 \mathrm{fl}$. (1692); 70 à $83 \mathrm{fl}$. (1693); 90 à 92 fl. (1694); 20 fl. (1698) (RAB, Npt, 5896 ; Ibidem, 5864, $\left.f^{o s} 20,51,73,107\right)$. Ook te Nantes werden op het einde van de $18^{\circ}$ eeuw in oorlogstijd enorme winsten gemaakt. De firma Chaurand schrijft in 1783: "Nous avons plus gagné pendant la guerre que nous ne pouvons perdre en paix " (J. Meyer, L'armement Nantais..., blz. 246).

150. Verzekeringspremie St-Malo-Oostende bedroeg te Antwerpen op 27 juli $169720 \%$ (RAB, Npt, 5887).

151. De loonlast bedroeg $3.441 \mathrm{fl}$. op een totale uitgave van $10.109 \mathrm{fl}$., dus meer dan $1 / 3$ (Ibidem, $4866 \mathrm{bis}$ ).

152. Dezelfde hoeker was te voeren in vredestijd door een bemanning van 9 mannen en 2 jongens. Hiervoor moesten alleen de masten gekort en de zeilen verbreed worden, Looten aan Vleeschouwer, 11 april 1698 (Ibidem, 5883). 
op winst tijdens de oorlogsjaren de Vlaamse reders moet gestimuleerd hebben. In hoever is ons niet bekend. Dit is immers slechts één voorbeeld en één vogel maakt nog geen lente ${ }^{153}$. Niet alle reizen hebben een gunstig resultaat afgeworpen. Reeds in de inleiding werd op de keerzijde van de medaille gewezen. Hoe groot is immers het verlies aan schepen door kapers of door storm ? Door kapers genomen was schip en lading verloren ${ }^{154}$; storm kan het schip gedeeltelijk beschadigen, zoals in het geval van het fregat de «St.-Anna », dat Oostende op 19 september 1697 verliet en Bordeaux eerst in januari 1698 binnenliep in een deerniswekkende toestand $\mathrm{nl}$. met gebroken masten en beroofd van zijn want. De scheepsherstellingen liepen zeer hoog op, zodat de reders uiteindelijk met een abnormaal groot verlies hadden af te rekenen ${ }^{155}$.

De animatie echter, waarvan de «fransvaart » in de jaren 1695-1698 blijk geeft, schijnt er op te wijzen dat de winst de zeer hoge risiko's dekte ${ }^{156}$. Om deze animatie te bepalen,

153. «Les exigences de l'historien économiste sont identiques: le fait isolé n'est que matériau d'attente, souvent précieux d'ailleurs ; la série homogène et continue seule fonde les conclusions » ( $R$. Richard, Le financement des armements maritimes du Havre au $X V I I I^{\mathrm{e}}$ siècle, in Revue d'bistoire économique et sociale, XLVII (1969), blz. 6). Ons voorbeeld is inderdaad niet alleenstaand. We kunnen het voorbeeld aanhalen van het schip van Frans Snoeck dat na een reis Nantes-Brugge zijn rekening afsloot op 21 mei 1694 met een boni van 10.200 fl. (RAB, Npt, 5864, fos 9495). Maar welke onkosten waren in dit boni verrekend?

154. Als voorbeeld halen we een passus uit een brief van Jan Stalpaert aan Vleeschouwer, Nantes 1 juni 1694 : «Schipper Jacobus de Wymmer neffens d'andere schepen, ontrent de 80 , met een convoyer voor t'cannael gedestineert liepen op $23^{5}$ passado voor de $3^{\text {e }}$ mael huijt en wierden gerencontreert van 3 engelsche oorloghscheepen, die de convoyer met 6 anderen tegen strand jougen en 2 fluyten met sout gelaeden naemen; d'andere salveerden. De Capitein van de convoyer stack de brand in sijn schip, een galioot met bomben gelaeden wiert door de vlam mede aengestoocken en de d'andere gebleeven, waer onder een van Dunquerque tschip d'Elisabeth, schipper Boussion, met sout gelaeden. Godt getroost de geintresseerde en verhelpe d'andere salvo » (RAB, Npt, 5896).

155. De vrachtprijs was 21 gulden wisselgeld; het saldo toonde een verlies van $2.336 \mathrm{fl}$. (Ibidem, $4866 \mathrm{bis}$ ).

156. Er is een duidelijke stijging van de belangstelling voor Bor- 
kan bv. verwezen worden naar het aantal schepen waarin Vleeschouwer in deze periode belangen had: de hoeker «St.-Fransois »; de hoeker, schipper Pieter de Corte; het fregat de «St.-Anna »; het fregat «De Pauw » en het fregat schipper Renier Oudestadt ${ }^{157}$. Daarbij moet men bedenken dat de «fransvaart » zich niet enkel tot Bordeaux beperkte. Er zijn nog Nantes, La Rochelle, Bayonne, waarmede Vlaanderen in een direkt kontakt stond en verder nog een drukke zouthandel met de baai van Bourgneuf onderhield.

Een zaak is echter zeker $\mathrm{nl}$. dat de op handen zijnde vrede in $1697 / 98$ iedere winstgevende onderneming uitsloot. De vrachtprijzen daalden tot hun vooroorlogs minimum en uit de brieven van Looten komt duidelijk naar voor dat het voor de Vlaamse schepen praktisch onmogelijk was een vracht te krijgen. De voor de hand liggende oplossing was de verkoop, wat dan ook blijkt te gebeuren met de schepen van Jacob de Wymer en Jan Looten te Rotterdam.

Dat de nog bestaande koopvaardij op de traditionele routes een uitzonderlijk moeilijke tijd tegemoet ging, kan getoetst worden aan volgend konkreet voorbeeld. In oktober 1698 koopt Charles Heuribloc ${ }^{158}$ te Brugge - langs Vleeschouwer om - een vierde part in een fluitschip de «St.Pieter », groot 140 vat, kapitein Passchier de Rudder, voor de prijs van $1.200 \mathrm{fl}^{\text {. wisselgeld }}{ }^{159}$. De eerste vier reizen

deaux waar te nemen, $\mathrm{cfr}$ het statistisch materiaal uitgegeven door J. De Smet, Tables de commerce..., in Hand. Kon. Comm. Gesch., XCIV (1930), blz. 190-195: er worden in 16954 schepen uit Bordeaux genoteerd, in 169617 en in 169724 .

157. Vleeschouwer aan Charles Francois de Pouillon te Gent, Nieuwpoort 10 december 1697 (Gent, Rijksarchief, Raad van Vlaanderen, $1^{\circ}$ reeks, 3955 ).

158. Charles Heuribloc, zoon van Charles, heer van Hondswalle, schepen van het Brugse Vrije, burgemeester van het Westkwartier, was gehuwd met Jeanne Pierloot. Hij stierf 15 september 1716 (J. Gailliard, Bruges et le Franc ou leur magistrature et leur noblesse, Brugge, 1857-1864, 6 dln., IV, blz. 391).

159. Vleeschouwer aan Heuribloc, Nieuwpoort 19 oktober 1698 : "Alsoo last hebbe ghestelt een vierde part int schip van schipper Passchier de Rudder dat UI onder mij sult hebben, conforme mij dito schip cost, dat present ' $t^{\prime}$ Ostende light, sijnde een fluijtbootje 
(oktober 1698 - juni 1700) vertoonden een nadelig saldo van $1.024 \mathrm{fl}$. wisselgeld ${ }^{160}$. Daarentegen vertoonde de afrekening van de boekhouder, Mattheus de Moor van Oostende, in juni 1702 een fiktief overschot van $362 \mathrm{fl}$. wisselgeld ${ }^{161}$, fiktief, omdat het schip tijdens de laatste reis verloren ging, zodat van het batig saldo niet de waardevermindering van het schip zou moeten gededuceerd worden, doch het totale kapitaal. De investering van Heuribloc was dus een fiasko op de ganse lijn, waarbij niet alleen zijn oorspronkelijk kapitaal van 200 pond groot verloren ging, maar waarbij hij tevens nog zijn vierde deel in de tekorten van de diverse reizen had bij te passen. Het zal aanleiding geven tot een proces, dat nog in 1720 hangende was.

Bij een dergelijke ekonomische konjunktuur ligt het voor de hand dat de Vlaamse reders zich nieuwe routes en nieuwe markten hebben trachten te verzekeren. Is het mogelijk dat deze druk van onderuit Bergeyck in 1698 dwong tot het oprichten van de Oostindische Kompagnie ? Deze laatste zal echter eerst in 1722 effektief worden en dan nog slechts voor een korte termijn. De buitenlandse konkurrenten zullen opnieuw paal en perk stellen aan een uitbreiding van de Vlaamse koopvaardij.

O. MUS.

van 140 vat groot, dat naer Bourdeaux sal seilen met d'eerste oostewint om nieuwe wijn, deel op vrecht en de partije voor schipsrekeninghe, waeruijt Ul jaerelijckx sijn provisie wijn sult hebben en de verhoope voor niete sult drincke...» (RAB, Npt, 5876).

160. Deze vier reizen waren de volgende:

Oostende - Bordeaux - Oostende (ok. 1698 - febr. 1699);

Oostende-Le Croisic-Riga - Oostende (april 1699-?);

Oostende-Nantes - Oostende (nov. 1699-jan. 1700);

Oostende-Kristianstad (Zweden)-Oostende (april 1700-juni 1700) (Ibidem).

161. "Over soo veele Ul comt over $1 / 4$ part in fl. 1.267.3.6 wgt par rekeninghe van den bouckhouder Mattheus de Moor over en de tot den tijdt tschip van schipper Passchier de Rudder is ghebleven in wgt fl. 362.1.0.» (Ibidem). 